\title{
REVIEW
}

\section{Thyroid hormone receptor localization in target tissues}

\author{
Cyril S Anyetei-Anum, Vincent R Roggero and Lizabeth A Allison \\ Department of Biology, College of William and Mary, Williamsburg, Virginia, USA \\ Correspondence should be addressed to L A Allison: laalli@wm.edu
}

\section{Abstract}

The thyroid hormone receptors, TR $\alpha 1, \operatorname{TR} \beta 1$ and other subtypes, are members of the nuclear receptor superfamily that mediate the action of thyroid hormone signaling in numerous tissues to regulate important physiological and developmental processes. Their most well-characterized role is as ligand-dependent transcription factors; TRs bind thyroid hormone response elements in the presence or absence of thyroid hormone to facilitate the expression of target genes. Although primarily residing in the nucleus, TR $\alpha 1$ and TR $\beta 1$ shuttle rapidly between the nucleus and cytoplasm. We have identified multiple nuclear localization signals and nuclear export signals within TR $\alpha 1$ and TR $\beta 1$ that interact with importins and exportins, respectively, to mediate translocation across the nuclear envelope. More recently, enigmatic cytoplasmic functions have been ascribed to other TR subtypes, expanding the diversity of the cellular response to thyroid hormone. By integrating data on localization signal motifs, this review provides an overview of the complex interplay between TR's dynamic transport pathways and thyroid hormone signaling activities. We examine the variation in TR subtype response to thyroid hormone signaling, and what is currently known about regulation of the variety of tissue-specific localization patterns, including targeting to the nucleus, the mitochondria and the inner surface of the plasma membrane.

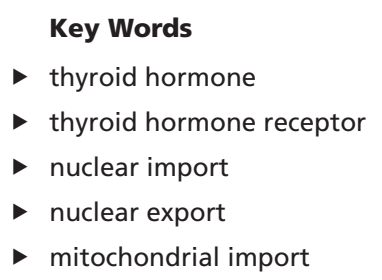

Journal of Endocrinology (2018) 237, R19-R34

\section{Introduction}

Thyroid hormone is essential for many diverse processes in nearly all vertebrate tissues, and abnormal thyroid hormone signaling underpins several human diseases (Laudet \& Gronemeyer 2002, Chen et al. 2013, Kim \& Cheng 2013, Mullur et al. 2014, Mondal et al. 2016, Mendoza \& Hollenberg 2017, van der Spek et al. 2017). Much of thyroid hormone action is mediated by the thyroid hormone receptors (TRs), members of the nuclear receptor superfamily that act as ligand-dependent transcription factors. By modulating the transcription of target genes in response to ligand, TRs play key physiological roles in the regulation of many aspects of development, growth and metabolism, including the regulation of mitochondrial activity (Flamant \& Gauthier 2013, Pascual \& Aranda 2013, Bernal 2017, Skah et al. 2017, Vella \& Hollenberg 2017, Wrutniak-Cabello et al. 2017). Thyroid hormone signaling is typically classified into two distinct pathways, nongenomic and genomic; however, these designations do not fully capture the subtleties of thyroid hormone action. To address the complexity of thyroid hormone signaling, a more precise nomenclature has recently been formulated (Flamant et al. 2017). In this new classification scheme, four types of thyroid hormone signaling are defined: type 1 is the canonical pathway in which liganded TR binds directly to DNA; type 2 describes liganded TR tethered to chromatin-associated proteins, 
but not bound to DNA directly; type 3 suggests that liganded TR can exert its function without recruitment to chromatin in either the nucleus or cytoplasm; and type 4 proposes that thyroid hormone acts at the plasma membrane or in the cytoplasm without binding TR, a mechanism of action that is emerging as a key component of thyroid hormone signaling (Kalyanaraman et al. 2014, Davis et al. 2016).

The biological effect of thyroid hormone in a given tissue depends on a number of factors: the amount of available hormone, the levels of different TR subtypes and their post-translational modifications, the type of heterodimerization partner and their interaction with corepressors and coactivators (Morte \& Bernal 2014). In addition, accurate translocation of TRs from their synthesis in the cytosol to their ultimate destination is essential for maintaining proper cellular functions and activities (Bonamy et al. 2005, Bonamy \& Allison 2006, FernandezMajada et al. 2007, Bondzi et al. 2011, Wang \& Li 2014). The thyroid hormone receptors are remarkably dynamic proteins. Although primarily residing in the nucleus, TR $\alpha 1$ and TR $\beta 1$ shuttle rapidly between the nucleus and cytoplasm, and recent characterization of TR 1 isoforms with cytoplasmic functions adds a surprising twist to the intricacies of the receptor's subcellular trafficking. The fine balance between nuclear import and export of TRs has emerged as a critical control point for modulating thyroid hormone-responsive gene expression (Subramanian et al. 2015, Roggero et al. 2016), while an additional layer of complexity is added by multiple modular, often overlapping, functional domains. General understanding of nuclear localization signal (NLS) and nuclear export signal (NES) structure, mitochondrial and membrane targeting signals, and how these motifs are regulated will assist in refining the understanding of the mechanism of action of TRs. In this review, we will focus on the mechanisms regulating the journey of TR from its site of synthesis in the cytoplasm to its final localization in target tissues, and how the receptor integrates gene expression across multiple levels in the cellular response to hormone. Before considering the cellular response to thyroid hormone, it is important to first examine the pathway by which thyroid hormone reaches target tissues and gains access to its intracellular receptors.

\section{Thyroid hormone signaling}

Thyroid hormone is produced through a feedback loop that includes the hypothalamus, pituitary and thyroid gland, commonly referred to as the hypothalamicpituitary-thyroid (HPT) axis (Medici et al. 2015, Mendoza \& Hollenberg 2017). The HPT axis involves a series of signal transduction cascades, where a signal sent from the hypothalamus eventually arrives at the thyroid gland, triggering release of thyroid hormone. In the circulatory system, the majority of total 3,5,3',5'-L-tetraiodothyronine (thyroxine, $\mathrm{T}_{4}$ ) and 3,5,3'-L-triiodothyronine $\left(\mathrm{T}_{3}\right)$ are bound with three different thyroid hormone carrying proteins: thyroxine-binding globulin, transthyretin and human serum albumin (Pappa et al. 2015, Mondal et al. 2016). Upon reaching the target tissue, thyroid hormones enter cells via uptake through specific membrane transporters, including the monocarboxylate transporters MCT8 and MCT10 (Abe et al. 2012, Bernal et al. 2015). The most extensively characterized transporter, MCT8, transports thyroid hormone exclusively and preferentially binds $T_{3}$; however, secondary thyroid hormone transporters have been described that can compensate for loss of MCT8 expression, including the heterodimeric L-type amino acid transporters (LATs), LAT1 and LAT2, and the organic anion-transporting polypeptide (OATP) family (Mendoza \& Hollenberg 2017).

Once in the cell, the intracellular concentration of thyroid hormone can be modified by the action of a suite of deiodinases. The prohormone $\mathrm{T}_{4}$ can be converted to the physiologically active hormone $\mathrm{T}_{3}$, or inactivated via conversion to $3,3^{\prime}, 5^{\prime}$-L-triiodothyronine (reverse $\mathrm{T}_{3}$, or $\mathrm{rT}_{3}$ ) within the cell. $\mathrm{T}_{3}$ and $\mathrm{rT}_{3}$ can be modified to form the physiologically active 3,5'-L-diiodothyronine $\left(\mathrm{T}_{2}\right)$ or the inactive $3,3^{\prime}$-L-diiodothyronine $\left(3,3^{\prime}-\mathrm{T}_{2}\right)$, respectively, to protect tissues from excess hormone (Dentice et al. 2013, Orozco et al. 2014, Mondal et al. 2016). Whether $T_{4}$ is directly involved in mediating gene expression remains a subject of debate. $\mathrm{T}_{4}$ is thought to primarily influence gene expression indirectly by cross-talk with other cell signaling pathways at the plasma membrane (Davis et al. 2016); however, there also is accumulating evidence that $\mathrm{T}_{4}$ can directly modulate gene expression, dependent on the TR subtype and other cellular cofactors (Galton 2017). $T_{3}$ is directly involved in mediating gene expression by binding to TR in either the cytoplasm or nucleus of the cell (Bunn et al. 2001). The intricate balance between thyroid hormone production and deiodination is critical for the regulation of TR-mediated gene expression, and the dysregulation of this process may contribute to type II diabetes mellitus, obesity, cardiovascular disease and some types of cancer (Ruiz-Llorente et al. 2011, Brent 2012, Kim \& Cheng 2013).

In addition to the type 1 canonical response mediated by nuclear TRs, thyroid hormone also has effects not 
exerted through the nuclear TRs; such effects were puzzled over early on to explain observations that thyroid hormone can, in some cases, initiate cellular responses that are too rapid to be attributed to transcription and translation (Davis et al. 2016, Flamant 2016). Although detailed coverage of type 4 actions of thyroid hormone is beyond the scope of this review, it is worth noting the existence of a hormone receptor that is associated with the plasma membrane structural protein $\alpha \mathrm{V} \beta 3$ integrin, a regulator of cell-cell and cell-extracellular matrix interactions (Martin et al. 2014, Mullur et al. 2014, Cvoro et al. 2016, Davis et al. 2016, Lin et al. 2016). This receptor binds $\mathrm{T}_{3}$ and $\mathrm{T}_{4}$ and stimulates certain cellular responses, such as the remodeling of the actin cytoskeleton that is a vital component of brain development in neurons and glial cells (Leonard \& Farwell 1997), and changes in the morphology of breast cancer cells (Flamini et al. 2017). The $\alpha \mathrm{V} \beta 3$ integrin-associated receptor has two thyroid hormone-binding sites, S1 and S2, which lead to the activation of phosphatidylinositol 3-OH kinase (PI3K) and ERK1/2 signaling pathways, respectively. The receptor is structurally unrelated and has no sequence homology to nuclear TR and, although it could be referred to as a 'thyroid hormone receptor,' this nomenclature should be avoided to prevent misconceptions about the nature of this noncanonical receptor. Type 3 signaling, mediated by transcriptionally inactive cytoplasmic TR isoforms, will be addressed later in this review.

\section{Nuclear localization and function of thyroid hormone receptors}

The type 1 genomic effects of TRs are twofold; TRs can act as repressors of specific genes in the absence of ligand and activators of these same genes in the presence of ligand. For some genes, the reverse is the case: unliganded TR acts as an activator, while liganded TR is a repressor. This dual role of TRs implies constitutive nuclear localization. Many studies early on in the field supported this restricted subcellular distribution for TR (Kumara-Siri et al. 1986, Macchia et al. 1992, Lee \& Mahdavi 1993, Andersson \& Vennstrom 1997, Zhu et al. 1998, Zhang \& Lazar 2000). However, we and others have shown that even though TR $\alpha 1$ and TR $\beta 1$ appear to be predominantly nuclear at steady state, in fact, the receptors are undergoing rapid nucleocytoplasmic shuttling in both the presence and absence of $\mathrm{T}_{3}$ (Baumann et al. 2001, Bunn et al. 2001), movement which can be visualized by heterokaryon assays or fluorescence recovery after photobleaching (Grespin et al. 2008, Subramanian et al.2015). Detailed investigation of TRs has revealed distinct, dynamic localization patterns for some variants. Analysis of the intracellular localization of TRs by biochemical fractionation, immunocytochemistry or indirect immunofluorescence assays has proved challenging overall, because of a lack of validated isoform-specific antibodies, and the difficulty in detecting endogenous TR subtypes that are less abundant in cells. Many studies have thus relied on transient transfection assays and expression of fluorescent protein-tagged TRs. With regards to nuclear localization, in our hands, there is no indication that overexpressing TRs leads to a more cytoplasmic localization by saturating the capacity of cells to transport proteins into the nucleus or that fluorescent protein tags alter localization. For example, in transfected NIH-3T3 (mouse) cells or HeLa (human) cells, neither of which express detectable levels of endogenous TR, both exogenous GFP-tagged TR $\alpha 1$ and untagged TR $\alpha 1$ detected by antibody staining show a primarily nuclear distribution at steady state (Bunn et al. 2001, Bonamy et al. 2005).

\section{Thyroid hormone receptor subtypes}

The thyroid hormone receptors are well conserved throughout vertebrate evolution, originating from a single TR gene early in animal evolution (Manzon et al. 2014); and there is evidence for nuclear TR-mediated responses to thyroid hormone in non-vertebrate lineages, including molluscs, echinoderms, cephalochordates and ascidians (Laudet \& Gronemeyer 2002, Darras et al. 2011, Huang et al. 2015, Taylor \& Heyland 2017). The vertebrate thyroid hormone receptors are encoded by two genes located on different chromosomes, NR1A1 and NR1A2, although due to ancestral gene duplication, some nonmammalian vertebrate species, including teleost fish, have two TRo-encoding genes (GalayBurgos et al. 2008, Darras et al. 2011). From these loci, a surprisingly diverse set of TR proteins are produced, through alternative splicing, alternative promoter usage and internal initiation codons. Intense investigation of rodent and human TRs continues to reveal new subtypes, while the number of subtypes identified in other species, as of yet, is more restricted (Buchholz et al. 2006, Kanaho et al. 2006, Nelson \& Habibi 2008, Politis et al. 2018). For example, chickens and ducks have at least three subtypes (TR $\alpha$, TR $\beta 2$, TR $\beta 0$ ) (Bishop et al. 2000); zebrafish produces two TR $\beta$ variants and at least three TR $\alpha$ isoforms that all act as functional nuclear receptors (Darras et al. 2011); two distinct TR $\alpha$ transcripts and one TR $\beta$ transcript have 
been isolated from the American alligator (Helbing et al. 2006); and the Atlantic halibut has two TR $\alpha$ and two TR $\beta$ isoforms (Galay-Burgos et al. 2008). The main focus of this review is on the well-characterized mammalian receptors, in particular TR $\alpha 1$ and TR $\beta 1$.

Not all of the mammalian TR proteins produced act as nuclear receptors, however, and the physiological significance of many of the nonreceptor isoforms remains a subject of investigation (Flamant \& Gauthier 2013, Mullur et al. 2014, Vella \& Hollenberg 2017). What is currently known about the intracellular localization and function of the mammalian TRs is summarized in Table 1 , and further described herein. The predominant isoforms generated by alternative splicing mechanisms include the bona fide nuclear receptors TR $\alpha 1$, TR $\beta 1, \operatorname{TR} \beta 2$, TR $\beta 3$ and TR $\beta 4$ (Tagami et al. 2010, Moriyama et al. 2016); and the nonreceptor TR variants that lack $\mathrm{T}_{3}$-binding ability, TR $\alpha 2$, TR $\alpha 3$ and TR $\alpha-\Delta \mathrm{E} 6$ (Casas et al. 2006).

TR $\alpha 1$ has the highest expression in bone, the gastrointestinal tract, cardiac and skeletal muscle and the central nervous system; TR $\alpha 2$ and TR $\alpha 3$ are predominant in the brain, kidney, testis, brown adipose tissue and skeletal muscle (Guissouma et al. 2014, Skah et al. 2017). TR $\alpha-\Delta \mathrm{E} 6$ is expressed in all tissues tested and can sequester TR $\alpha 1$ in the cytoplasm (Casas et al. 2006). $\mathrm{TR} \alpha 2$ is found consistently in mammals but not in other species. Although a dominant negative function has been attributed to mammalian TR $\alpha 2$, which is widely co-expressed with TR $\alpha 1$, the physiological relevance has remained a puzzle, particularly since it is unexplained why it would be necessary for TR $\alpha 2$ to counter-balance normal
TR activity in mammals but not in nonmammalian species (Vennstrom et al. 2010). There is recent compelling evidence, however, that TR 22 modulates thyrotropinreleasing hormone gene expression in the hypothalamus (Guissouma et al. 2014). In addition, four truncated forms of TR $\alpha 1$ (full-length, $46 \mathrm{kDa}$ ) originate from alternative internal AUG translation initiation codons in TR 1 mRNA and are named based on their molecular masses: p43 starts at the equivalent of methionine-39 (Met ${ }^{39}$ ) in the full-length receptor, p33 starts with Met ${ }^{120}$, p30 starts with Met ${ }^{122}$ and p28 starts with Met $^{150}$ (Kalyanaraman et al. 2014, Wrutniak-Cabello et al. 2017) (Fig. 1). Finally, other truncated forms of TR $\alpha$, TR $\Delta \alpha 1$ and TR $\Delta \alpha 2$ are produced from an internal promoter in intron 7; they contain only the C-terminus of the ligand-binding domain (LBD) and are expressed in the brain, lung and gut (Chassande et al. 1997, Davis et al. 2016). TR $\Delta \alpha 1$ has been proposed as a candidate mediator of $\mathrm{T}_{4}$ binding in the cytoplasm, potentially playing a role in regulating actin polymerization (Davis et al. 2016).

TR $\beta 1$ is most abundant in the liver, kidney and the inner ear; TR $\beta 2$ is predominant in the hypothalamus, pituitary, cochlea and retina; and TR $\beta 4$ is ubiquitously expressed, with relatively high expression in the brain and kidney (Flamant \& Gauthier 2013, Hahm \& Privalsky 2013, Mullur et al. 2014, Vella \& Hollenberg 2017). Other minor isoforms of TR $\beta 1(52-\mathrm{kDa})$ also exist; for example, two isoforms are alternatively translated from TR $\beta 1$ mRNA, with TR $\beta 3$ (44.6-kDa) appearing to act as a functional receptor in rat (Flamant \& Gauthier 2013), and TR $\Delta \beta 3$ (32.8-kDa) functioning as a ligand-responsive

Table 1 Cellular localization and function of mammalian TR $\alpha$ and TR $\beta$ isoforms.

\begin{tabular}{l} 
Receptors \\
\hline TR $\alpha$ (NR1A1) \\
TR $\alpha 1$ \\
p46 (full-length) \\
p43 \\
p33 \\
p30 \\
p28 \\
TR $\alpha 2$ \\
TR $\alpha 3$ \\
TR $\Delta \alpha 1$ \\
TR $\Delta \alpha 2$ \\
TR $\alpha-\Delta$ E6 \\
TR $\beta(N R 1 A 2)$ \\
TR $\beta 1$ \\
TR $\beta 2$ \\
TR $\beta 2 \Delta$ \\
TR $\beta 3$ \\
TR $\triangle \beta 3$ \\
TR $\beta 4$
\end{tabular}

Cellular localization

Nuclear

Mitochondrial matrix

Unknown

Plasma membrane

Mitochondrial inner membrane

Nuclear

Nuclear

Unknown

Unknown

Cytoplasm

Predominantly nuclear Predominantly nuclear Predominantly nuclear Predominantly nuclear Predominantly nuclear Predominantly nuclear
Known or hypothetical function(s)

Transcriptional activation/repression Transcriptional activation/repression Unknown

Signaling cascade

Signaling cascade

Possible antagonist of TR action Possible antagonist of TR action Possible antagonist of TR action Possible antagonist of TR action Inhibitor of TR activity

Transcriptional activation/repression Transcriptional activation/repression Possible transcriptional regulation Transcriptional activation/repression Dominant negative antagonist Weak antagonist of TR action 


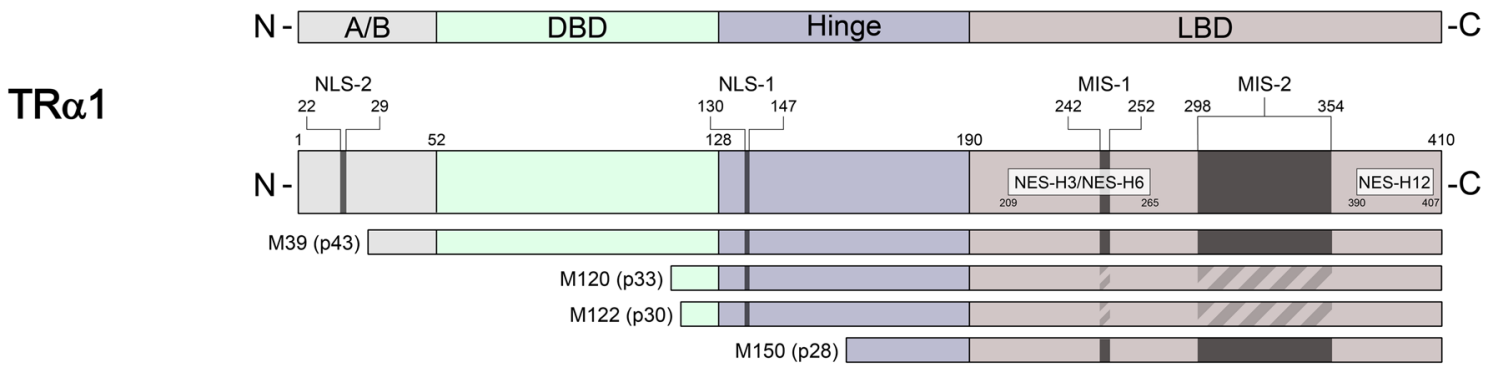

TRß1

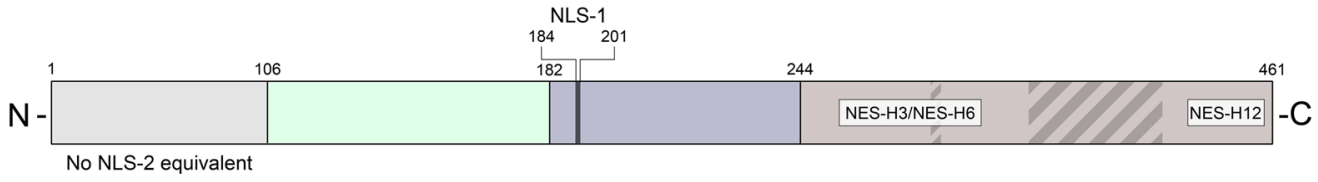

TR $\beta 2$

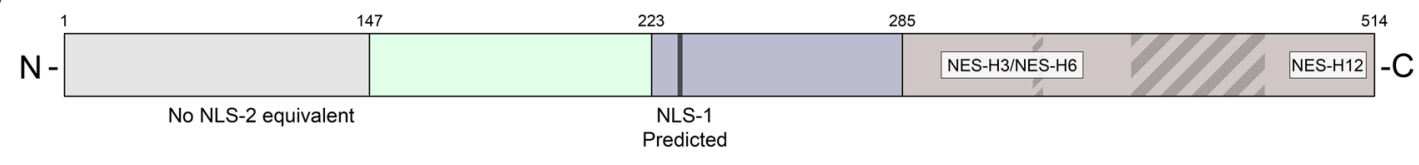

Figure 1

Thyroid hormone receptor (TR) major subtypes and localization signals. The structural diagram (not to scale) of TR $\alpha 1$, TR $\beta 1$ and TR $\beta 2$ shows nuclear localization signal (NLS), nuclear export signal (NES) and mitochondrial import sequence (MIS) motifs, where known (solid bar) or predicted (striped bar) based on sequence homology. The positions of localization signals are indicated in relation to the respective individual domains of TR: $\mathrm{N}$-terminal A/B domain (A/B), DNA-binding domain (DBD), hinge domain and ligand-binding domain (LBD). The TR 1 mRNA encodes several forms of truncated TR by translation initiation from internal AUG sites encoding methionine (M); amino acid residue numbers correspond to the position in full-length TR $\alpha 1$.

dominant negative antagonist (Williams 2000). In addition, an elongated form of TR $\beta 2$, termed $\operatorname{TR} \beta 2 \Delta$, has been proposed to function as a nuclear receptor in the rat pituitary gland (Zhao et al. 2014). In this review, we will focus on the TR $\alpha$ and TR $\beta$ isoforms where intracellular localization and targeting signals have been investigated in more detail.

\section{Functional domains of the thyroid hormone receptor}

The thyroid hormone receptor consists of four modular domains that are evolutionarily conserved among the nuclear receptor superfamily (Fig. 1): a variable N-terminal A/B domain, which contains a region involved in transactivation, activation function-1 (AF-1); a central DNA-binding domain (DBD) comprised of two zinc fingers; a C-terminal LBD, which also includes dimerization interfaces and activation function-2 (AF-2); and a linker or hinge region between the LBD and DBD that contributes to DNA binding, activation function and repression, ligand binding and corepressor interactions (Nascimento et al. 2006, Pawlak et al. 2012, Mondal et al. 2016, Zhang et al. 2018). TR $\alpha 1$ and TR $\beta 1$ both contain AF-1 domains involved in the transcriptional response to

\begin{tabular}{|c|c|}
\hline http://joe.endocrinology-journals.org & (C) 2018 Society for Endocrinology \\
\hline tps://doi.org/10.1530/JOE-17 & $\begin{array}{l}\text { Published by Bioscientifica Ltd. } \\
\text { Printed in Great Britain }\end{array}$ \\
\hline
\end{tabular}

hormone; while the TR $\beta 2$ isoform, which differs from TR $\beta 1$ in the A/B domain, has a unique hormone-independent AF-1 domain that recruits coactivators (Tomura et al. 1995, Oberste-Berghas et al. 2000).

\section{Ligand-binding domain conformation}

The LBD of TR is composed of $12 \alpha$-helices that form a hollow pocket lined with hydrophobic residues. The ligandbinding site is highly flexible, and the structural details underpinning receptor activation after $\mathrm{T}_{3}$ binding are complex (Schweizer et al. 2017). The twelfth helix contains the ligand-dependent activation domain, AF-2 (Figueira et al. 2011). Helix 12 forms a short pivoting structure that can adopt different conformations. In the absence of $\mathrm{T}_{3}$, helix 12 is in an extended position and the corepressorbinding groove is occupied by the corepressor nuclear receptor (CoRNR)-box helical motifs found in silencing mediator for retinoid or thyroid-hormone receptors (SMRT) and nuclear receptor co-repressor 1 (N-CoR1). Binding of $\mathrm{T}_{3}$ may induce a hormone-dependent 'mousetrap' mechanism (Moras \& Gronemeyer 1998, Sonoda et al. 2008, Flamant 2016), where helix 12 rotates to swing shut and close off the pocket around $\mathrm{T}_{3}$. As a result of this conformational change, a novel docking surface forms 
for interaction with LXXLL motifs (L denotes leucine; $\mathrm{X}$ denotes an undetermined amino acid) of a transcriptional coactivator (Rosen \& Privalsky 2011). A refinement of this model suggests that TR helix 12 functions as a 'selective gatekeeper' that actively discriminates between different forms of corepressor even in the unliganded receptor (Rosen \& Privalsky 2009); and other models propose that rearrangements in a mobile part of the LBD comprising helix 3 , the loop between helix 1 and helix 2 and nearby $\beta$-sheets, play a greater role in ligand dissociation than repositioning of helix 12 (Martinez et al. 2006). Mutations that disrupt helix 12 alter corepressor specificity as well as $\mathrm{T}_{3}$-mediated release of corepressors (Rosen \& Privalsky 2009). Recent $\mathrm{X}$-ray crystallographic structural studies have revealed a second ligand-binding site in TR located between helices 9 and 11 that may interact with $\mathrm{T}_{4}$ (Souza et al. 2014).

\section{Nuclear import and export signals}

The nuclear transport process provides a central regulatory point for coordinating cell signaling and gene expression. Macromolecules known as nuclear pore complexes (NPCs) are the regulatory gatekeepers of the entry and exit of nuclear proteins and allow for the passive diffusion of small molecules less than 40-kDa (Li et al. 2016). NPCs are distributed throughout the nuclear envelope, embedded at sites within the luminal space between the outer and inner membrane of the nuclear envelope (Tran et al. 2014, Cautain et al. 2015). They are octagonally symmetric cylindrical structures made up of proteins termed nucleoporins or Nups, which act to anchor the NPC in the nuclear envelope and provide interaction domains for nuclear proteins to translocate through a central channel (Hayama et al. 2017). The translocation of nuclear proteins through the NPCs is typically facilitated by karyopherin $\beta$-like family members (importins and exportins), with each member performing a distinct nuclear import, export or bidirectional transport function (Chook \& Suel 2011, Kimura \& Imamoto 2014).

Our systematic characterization of NES and NLS motifs by site-directed mutagenesis has elucidated the mechanics of TR nuclear localization (Mavinakere et al. 2012). In-depth analysis of TR $\alpha 1$ and TR $\beta 1$ structure reveals that the two subtypes both contain a classical bipartite NLS, named NLS-1, residing in the hinge region, and a second monopartite NLS, termed NLS-2, located in the A/B domain of TR $\alpha 1$ that is absent in TR $\beta 1$ (Fig. 1) (Mavinakere et al. 2012). RNAi and coimmunoprecipitation assays show that members of the importin family of karyopherins, specifically importin 7 , importin $\beta 1$ and adapter importin $\alpha 1$ recognize these NLSs and directly mediate the nuclear import of TRs through the NPC (Roggero et al. 2016) (Fig. 2). In support of the importance of NLS-1 for efficient nuclear localization, an isoform that lacks the hinge domain, TR $\alpha-\Delta \mathrm{E} 6$, has a strikingly altered localization compared with TR $\alpha 1$; TR $\alpha-\Delta \mathrm{E} 6-\mathrm{GFP}$ was shown to be predominantly expressed in the cytoplasm with minor nuclear fluorescence (Casas et al. 2006). In addition, TR $\beta 4$ is primarily localized to the nucleus, and mutation of two putative NLSs near the hinge region results in a whole cell distribution of the receptor (Moriyama et al. 2016).

In an earlier study, we showed that TR $\alpha 1$ exits the nucleus through two pathways, one dependent on the export factors CRM1 and calreticulin and the other CRM1 independent (Grespin et al. 2008). In a subsequent study, we also identified a novel NES in helix 12 of the LBD of TR (NES-H12). Another novel NES motif spans helix 3 and helix 6 (NES-H3/H6) (Mavinakere et al. 2012) (Fig. 1). Notably, these NES motifs are not sensitive to leptomycin B, a specific inhibitor of CRM1, suggesting that they mediate the CRM1-independent export pathway followed by TR. Follow-up work by RNAi has shown that multiple exportins

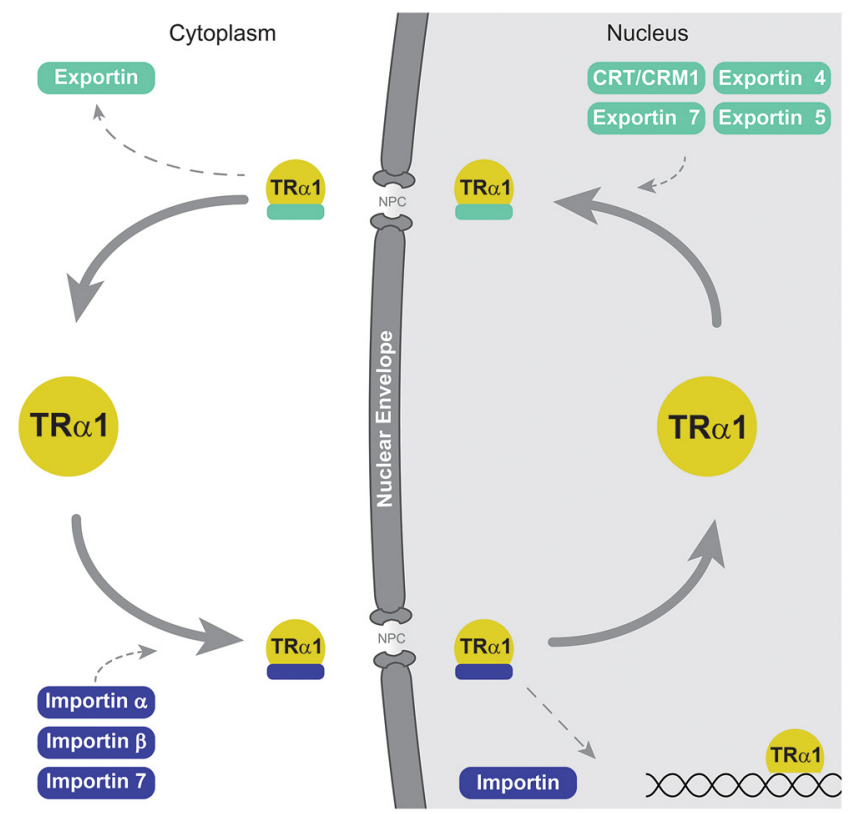

Figure 2

Thyroid hormone receptor nucleocytoplasmic shuttling pathway. The well-characterized pathway for TR $\alpha 1$ is depicted. TR $\alpha 1$ binds to specific importins in the cytoplasm, as indicated. The TR $\alpha 1$-importin complex passes through a nuclear pore complex (NPC) embedded in the nuclear envelope into the nucleus, where the complex is disassembled and TR $\alpha 1$ binds to target genes. TR $\alpha 1$ exits the nucleus through the NPC in association with specific exportins or calreticulin (CRT)/CRM1. TR $\beta 1$ follows a similar nucleocytoplasmic shuttling pathway, but nuclear import is solely mediated by the importin $\alpha 1$ /importin $\beta 1$ complex. 
influence TR export, including exportins 4, 5 and 7 (Subramanian et al. 2015). Not surprisingly, the two NLSs found in TR $\alpha 1$ act to confer strong nuclear localization to the receptor; we hypothesize that TR $\beta 1$ 's small cytosolic population (Zhu et al. 1998, Baumann et al. 2001) may reflect an altered balance of NLS and NES activity (Mavinakere et al. 2012, Zhang et al. 2018) (Fig. 3). Although multiple NLS and NES motifs exist in a variety of nuclear proteins, how these multiple signals interact collectively remains unclear (Bonaldi et al. 2003, Mavinakere et al. 2012, Umemoto \& Fujiki 2012, Lu et al. 2014, Dai et al. 2015, Panayiotou et al. 2016). Once TRs are directed into the nucleus and released from importin, they can then interact with target genes to modulate gene expression in response to hormone.

\section{Thyroid hormone receptor gene activation and sillencing}

A multifaceted cascade of events results in binding of TRs to thyroid hormone response elements (TREs) and culminates in the modulation of target gene expression in response to thyroid hormone (Brent 2012, Bernal \&
Morte 2013, Ayers et al. 2014, Vella \& Hollenberg 2017). Thyroid hormone receptors often heterodimerize with the retinoid $\mathrm{X}$ receptor (RXR), expanding the range of $T_{3}$ responsiveness for genes within the same cell (Diallo et al. 2007, Flamant 2016). On positive TREs, corepressors, such as N-CoR1 or N-CoR2 (also known as SMRT) and histone deacetylase (HDAC), are bound in the absence of ligand to TR, leading to repression of target gene expression (Xu et al. 1999, Oberoi et al. 2011, Mendoza et al. 2017). Upon ligand binding, TR undergoes a conformational change, resulting in a new set of activator proteins bound to the receptor, such as SRC-1 (p160/steroid receptor coactivator 1) and histone acetyltransferase (HAT). This leads to changes in chromatin structure and the subsequent transcription of the target gene (McKenna et al. 1999, Soriano et al. 2011, Dasgupta \& O'Malley 2014). In addition to unliganded TR bound to positive TREs, chromatin immunoprecipitation sequencing (ChIP-seq) analysis of endogenous TR in mouse liver tissue suggests that the receptor's interaction with chromatin is highly dynamic and that it can be recruited to chromatin in a ligand-dependent
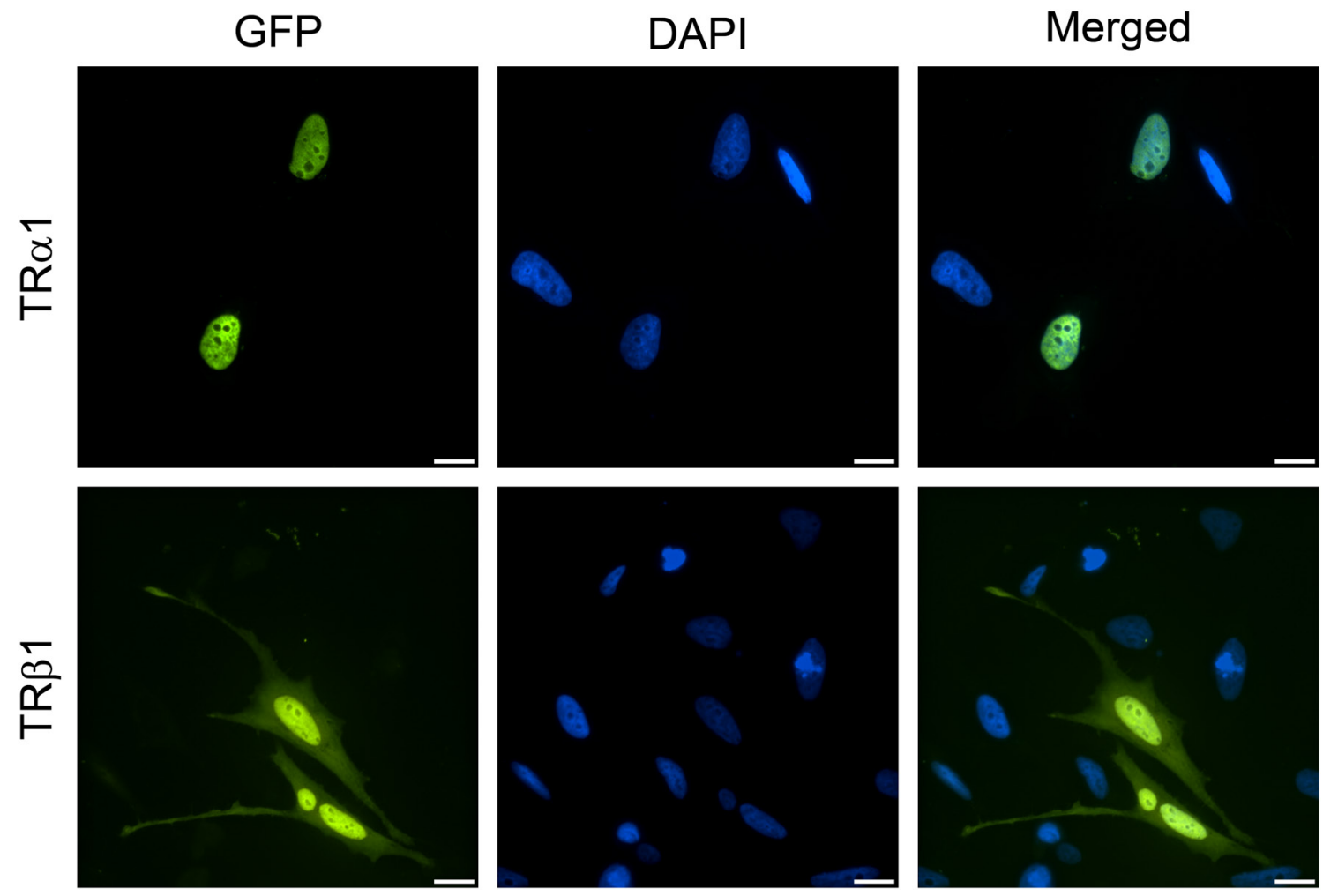

Figure 3

Distinct intracellular localization patterns for TR $\alpha 1$ and TR $\beta 1$. HeLa cells transfected with expression plasmids for green fluorescent protein (GFP)-tagged TR $\alpha 1$ and TR $\beta 1$ were analyzed by fluorescence microscopy after staining for DNA with DAPI to visualize the nucleus. GFP-TR $\alpha 1$ predominantly localizes to the nucleus; GFP-TR $\beta 1$ also localizes to the nucleus but has a slight cytoplasmic population. Scale bar, $10 \mu \mathrm{m}$. 
manner (Grontved et al. 2015). These findings align with an earlier report that used fluorescence recovery after photobleaching (FRAP) to show that TR $\beta 1$ moves rapidly within the nucleus and that ligand binding does not affect its mobility (Maruvada et al. 2003). A recent study in mice suggests that TR target genes respond to $\mathrm{T}_{3}$ based on the availability of specific corepressors and coactivators, providing an explanation for tissue-specific responses to similar amounts of $\mathrm{T}_{3}$ (Vella et al. 2014). In addition to activating transcription on positive TREs, TRs can also repress gene expression, possibly by binding to putative negative TREs in a $\mathrm{T}_{3}$-dependent manner (Bernal \& Morte 2013). In this instance, N-CoR1 and SMRT appear to play a role in determining $\mathrm{T}_{3}$ sensitivity, suggesting that corepressors can be recruited to TR in the presence of $\mathrm{T}_{3}$ (Astapova et al. 2011, Astapova \& Hollenberg 2013, Shimizu et al. 2015). The mechanism remains unclear, however, and a recent genome-wide analysis of chromatin occupancy of TRs in neural cells does not appear to support the hypothesis that liganded TR acts directly as a transcription repressor (Chatonnet et al. 2013). Further, ChIP-seq studies in hypothyroid and hyperthyroid mouse liver cells suggest that negative regulation instead may be mediated by diminished TR recruitment in the presence of $T_{3}$ (Ramadoss et al. 2014).

\section{Cytoplasmic functions of the thyroid hormone receptor}

For many years, the focus in the field was on characterizing the nuclear function of TRs, but now their emerging roles in the cytoplasm also must be considered. Study of the functional domains of full-length $\mathrm{TR} \alpha 1$ (p46) and the truncated isoforms p43, p33, p30 and p28 has revealed conflicting intracellular targeting signals within TR $\alpha 1$ that can direct the proteins to the nucleus, mitochondria or the inner surface of the plasma membrane (Mavinakere et al. 2012, Kalyanaraman et al. 2014, Wrutniak-Cabello et al. 2017) (Figs 1 and 4). TR 1 p43 and p28 are targeted to the mitochondrial matrix and mitochondrial inner membrane, respectively. The biological function of TR $\alpha 1$ p33 remains unknown, but p30 is post-translationally modified via palmitoylation and colocalizes with caveolin- 1 at the inner surface of the plasma membrane. Upon binding $\mathrm{T}_{3}$, the nitric oxide (NO)-cyclic guanosine monophosphate (cGMP)-protein kinase G (PKG) signaling cascade is activated and stimulates the proliferation and survival in multiple cell types (Hiroi et al. 2006, Kalyanaraman et al. 2014, Wrutniak-Cabello et al. 2017).
Studies in diverse cells types, including human adiposederived stem cells (hADSC), human primary osteoblasts, mouse osteoblast-like MC3T3 cells, monkey kidney cells (CV-1), neonatal rat ventricular myocytes (NRVM), and mouse cardiomyocytes (HL-1), have revealed TR subtypes localized to the mitochondria, plasma membrane and cytoplasmic compartments in a tissue-specific manner (Carazo et al. 2012, Kalyanaraman et al. 2014, Cvoro et al. 2016, Wadosky et al. 2016). Of particular interest, human ADSCs are multipotent adult stem cells with the capacity to differentiate into adipocytes, chondrocytes and osteocytes, and they express TR $\alpha 1, T R \alpha 2$ and TR $\beta 1$ at variable levels. TR intracellular localization was investigated by indirect immunofluorescence assay and, interestingly, all subtypes showed cytoplasmic localization. Further examination via double immunostaining of TR $\alpha 1$ and TR $\alpha 2$ with a mitochondrial marker showed a predominantly mitochondrial localization for TR $\alpha 1$ proteins (Psarra \& Sekeris 2008, Carazo et al. 2012, Wadosky et al. 2016). Although western blot analysis was not performed to visualize protein size, these findings suggest that truncated forms of TR were reliably being detected by the antibodies used in this study.

\section{Mitochondrial targeting}

A major compartment of thyroid hormone accumulation within the cell is the mitochondria (Bassett et al. 2003, Psarra \& Sekeris 2008, Davis et al. 2016, Wrutniak-Cabello et al. 2017). The major effect of thyroid hormone on mitochondrial activity has been partially explained by reports of truncated TR $\alpha 1$ variants localizing to the mitochondria of different mammalian tissues, such as liver, brown and white adipose tissue, red and white muscle, heart, tongue and testis (Carazo et al. 2012, Fumel et al. 2013, Wrutniak-Cabello et al. 2017). In addition, a truncated $\operatorname{TR} \beta\left(\mathrm{TR}_{\beta} \mathrm{A} 1\right)$ localizes to the mitochondria in Xenopus laevis (South African clawed frog) oocytes (Saelim et al. 2007). TR $\alpha 1$ p43 is targeted to the mitochondrial matrix, while TR $\alpha 1$ p28 is targeted to the mitochondrial inner membrane (Carazo et al. 2012, Kalyanaraman et al. 2014, Wrutniak-Cabello et al. 2017) (Fig. 4). TR $\alpha 1$ p43 displays an N-terminal deletion that lacks NLS-2, but still possesses NLS-1 in the hinge region (Fig. 1). In contrast, TR $\alpha 1$ p28 displays an N-terminal deletion of the A/B domain, the DBD and NLS-1. Neither p43 nor p28 possesses a canonical mitochondrial import sequence (MIS). Nonetheless, sequences within helices 5, 10 and 11 in the C-terminal LBD of p43 and p28 have been identified that are necessary for mitochondrial import (Carazo et al. 2012) (Fig. 1). Helix 5, 


\begin{tabular}{l|l|l|l|l|}
$\begin{array}{l}\text { Journal of } \\
\text { Endocrinology }\end{array}$ & C S Anyetei-Anum et al. & $\begin{array}{l}\text { Thyroid hormone receptor } \\
\text { localization }\end{array}$ & $\mathbf{2 3 7 : 1}$ & $\mathbf{R 2 7}$ \\
\hline
\end{tabular}

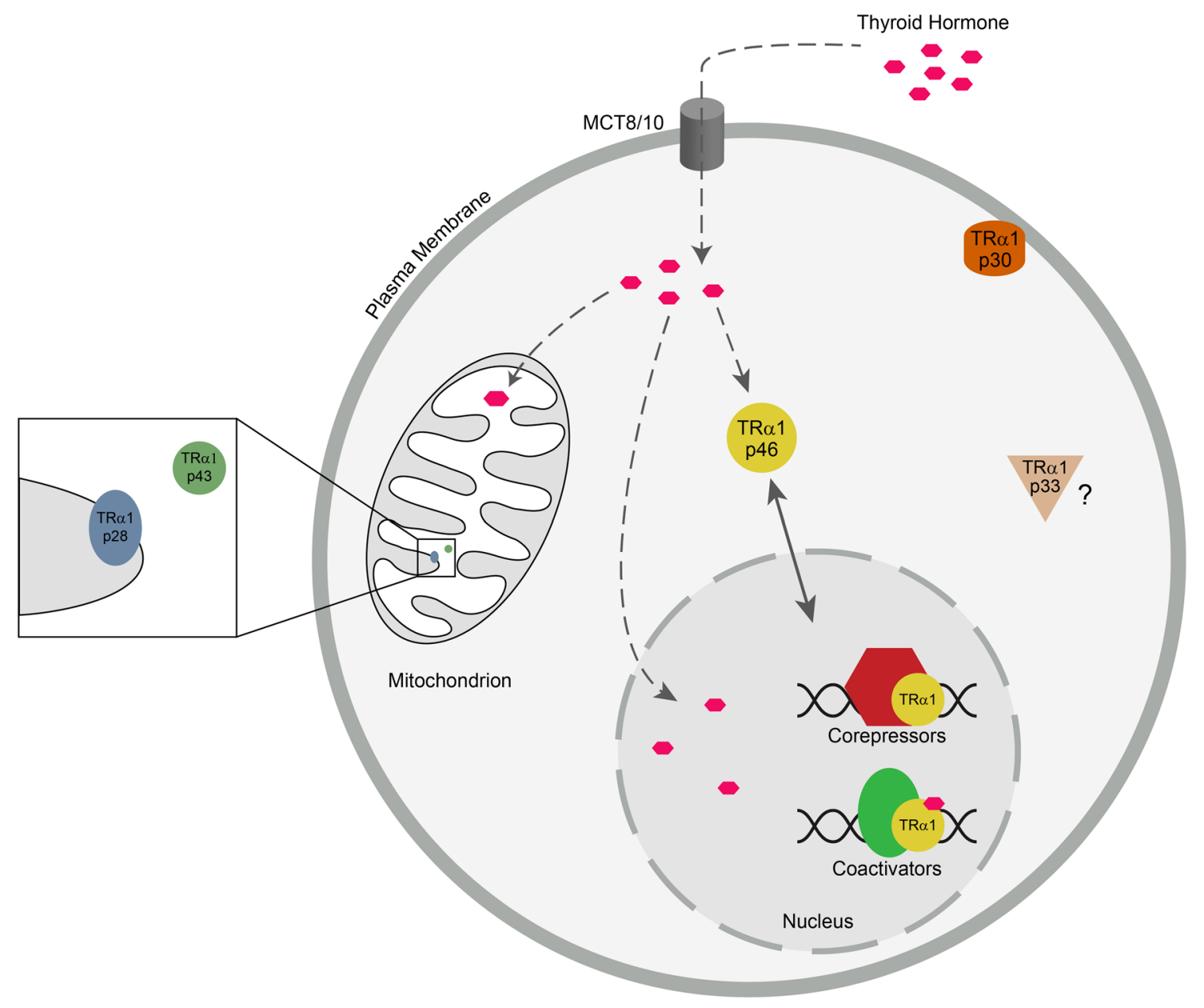

\section{Figure 4}

Model for localization of TR $\alpha 1$ isoforms to the mitochondria, plasma membrane and nucleus. TR $\alpha 1$ mRNA yields different forms of truncated TR by internal translation initiation. Once synthesized in the cytosol, the different forms localize to different intracellular compartments. TR 1 p28 and TR 1 p43 localize to the mitochondrial inner membrane and matrix, respectively. TR $\alpha 1$ p30 localizes to the inner surface of the plasma membrane, where it can bind to thyroid hormone to mediate thyroid hormone signaling. The specific localization and function of TR 1 p 33 remains unknown. Full-length TR $\alpha 1$ (TR $\alpha 1$ p46) localizes to the nucleus where it modulates target gene expression in response to thyroid hormone, in association with corepressors and coactivators. Thyroid hormone enters the cell through the monocarboxylate 8 and 10 transporters (MCT8/10).

spanning amino acids $242-252$ of TR $\alpha 1$, was found to drive an atypical mitochondrial import process independent of ATP and the mitochondrial membrane potential; whereas helices 10-11, spanning amino acids 298-354, induced a typical mitochondrial import process sensitive to ATP and the mitochondrial membrane potential. Whether these two mitochondrial import sequences, MIS1 and MIS2, are functional or not, is proposed to depend on the 'permissive' role of the N-terminus of TR $\alpha 1$ (Carazo et al. 2012). In this model, conformational changes of the protein, dependent on the flexibility of the hinge region, would disrupt the functionality of NLS-1 in the hinge region and induce the activity of the mitochondrial import sequences (WrutniakCabello et al. 2017). Interestingly, TR $\beta 1$ harbors these conserved MIS1 and MIS2 motifs and lacks NLS-2 in the
$\mathrm{N}$-terminal A/B domain (Fig. 1), but there is no evidence of functionality of the MIS motifs. It is of interest to determine the exact nature of the $\mathrm{N}$-terminal $\mathrm{A} / \mathrm{B}$ domain sequence in regulating localization of TRs to the mitochondrial or nuclear compartments.

\section{Plasma membrane targeting}

Beyond type 1 genomic actions within the mitochondria, type 3 actions of TR are primarily associated with its localization to the plasma membrane. The alternative translation product TR $\alpha 1 \mathrm{p} 30$ is targeted to the plasma membrane where it is proposed to play a key role in mediating signaling pathways involved in cell survival and proliferation (Carazo et al. 2012, Kalyanaraman 
et al. 2014, Wrutniak-Cabello et al. 2017). Further, there is tissue-specific variation in p30's localization to the plasma membrane (Kalyanaraman et al. 2014). In murine primary osteoblasts, TR $\alpha 1$ p30 associates with lipid rafts (cholesterol-rich plasma membrane microdomains that contain caveolin-1) to function as a unique signal transduction platform. In contrast, in MC3T3 cells, TR $\alpha 1$ p30 associated with caveolin-1, nitric oxide synthase 3 (NOS3), protein kinase G type II (PKGII) and the tyrosine kinase Src. These data point to the possibility that TR $\alpha 1$ p28 localizes to the mitochondrial inner membrane following a similar mechanism (Kalyanaraman et al. 2014), and provide an understanding of how certain membrane-targeted proteins interact with caveolin to reach the plasma membrane (Hayer et al. 2010).

\section{A role for post-translational modification in TR localization}

Post-translational modifications (PTMs) play a significant role in the regulation of protein structure, enzymatic activity, stability or degradation, subcellular localization, protein-protein interactions and diverse cell signaling (Rodriguez 2014, Lin et al. 2015, Azevedo \& Saiardi 2016, Drazic et al. 2016). Many amino acid side chains such as cysteine $(\mathrm{C})$, serine $(\mathrm{S})$, threonine $(\mathrm{T})$ and tyrosine (Y) are post-translationally modified; however, the amino acid lysine $(\mathrm{K})$ is targeted by an extremely high number of PTMs including methylation, ubiquitination, sumoylation and acetylation. Thyroid hormone receptors, and other nuclear receptors, undergo PTMs that influence transcriptional activity and subcellular localization (Cui et al. 2004, Lin et al. 2005, Sanchez-Pacheco et al. 2009, Abdel-Hafiz \& Horwitz 2014, Faresse 2014). For example, the association of TR $\alpha 1$ p30 with the plasma membrane is mediated by palmitoylation, a post-translational lipid modification. Consequently, it has been predicted that cysteine (Cys) ${ }^{254}$ and Cys ${ }^{255}$ palmitoylation is necessary to localize p30 to the plasma membrane (Kalyanaraman et al. 2014).

For nuclear TRs, phosphorylation regulates DNA binding and transcriptional activation, and it has been shown that phosphorylation of one or more sites in TR $\alpha 1$ enhances nuclear retention or inhibits nuclear export but is not directly involved in nuclear import (Nicoll et al. 2003). Intriguingly, a recent study suggests the phosphorylation of TR $\beta 1$ may play a role in promoting nuclear localization in serum-starved Chinese hamster ovary (CHO) cells. FLAG-tagged TR $\beta 1$ was shown to form a cytoplasmic complex with the p85 regulatory subunit of PI3K and the Src family kinase Lyn (Martin et al. 2014). Complex formation was dependent on two phosphotyrosine motifs in the second zinc finger of TR $\beta 1$ that are not conserved in TR $\alpha 1$. When hormone was added, the complex dissociated, allowing PI3K activity to increase and TR $\beta 1$ to move into the nucleus to regulate transcription. It will be of interest to extend these studies to tracking receptor movement in live cells. The authors suggest that dramatic shifts in localization may not be observable with GFP-tagged receptors, because the GFP tag might interfere with PI3K association; however, their qualitative observations of receptor distribution are consistent with the variability we see in populations of cells expressing GFP-TR $\beta 1$. As shown in Fig. 3, GFP-TR $\beta 1$ typically has a greater cytosolic population than GFP-TR $\alpha 1$, and we find TR $\beta 1$ distributions ranging from whole cell to primarily nuclear. For critical analysis of the fine nuances of receptor localization, rigorous quantification of the nucleus vs cytoplasmic distribution by fluorescence intensity measurements will be essential.

Acetylation sites that are important for transcriptional activity have been identified in the hinge domain of TR, corresponding to K130, K134 and K136 in human TR $\alpha 1$ (Sanchez-Pacheco et al. 2009), and to K184, K188 and K190 in TR $\beta 1$ (Lin et al. 2005). These lysines are integral components of NLS-1 (Mavinakere et al. 2012), suggesting that acetylation state could have an impact on NLS activity. Whether this PTM is important for modulating the nuclear localization of TR subtypes is under investigation.

It is known that ubiquitination of liganded $\mathrm{TR} \alpha 1$ targets the receptor for rapid proteasome-mediated degradation (Bondzi et al. 2011). Recently, it was reported that monoubiquitination of $\mathrm{TR} \alpha 1$ within its LBD results in a shift in the diffuse intranuclear localization of TR $\alpha 1$ toward the nuclear periphery in cardiomyocytes (Wadosky et al. 2016). TR $\alpha 1$ activity stimulates hypertrophy in cardiomyocytes, and although TR $\alpha 2$ and TR $\beta 1$ are present in this cell type, they lack this function. Muscle-specific ubiquitin ligase muscle ring finger-1 (MuRF1) (Rodriguez et al. 2015) was shown to monoubiquitinate TR $\alpha 1$ in vitro; however, specific lysine sites have not yet been identified and monoubiquitinated forms have not been detected in vivo (Wadosky et al. 2016). Whether polyubiquitination or monoubiquitination directly modulates TR nucleocytoplasmic shuttling remains to be determined.

Several studies have provided evidence that sumoylation of TR plays an essential role in fine-tuning TR regulation of gene expression. SUMO modification 
sites have been identified at K283 and K389 of TR 1 (positioned in NES-H3/H6); and at K50 (A/B domain within AF-1), K146 (DBD) and at K443 (near the NES-H12 motif) of TR $\beta 1$ (Liu et al. 2012, 2015, Weitzel 2016). Given the proximity of the SUMO-modified lysines to NES motifs, sumoylation is also under study for its impact on NES activity and TR nuclear localization.

Taken together, these reports provide insights into the possible interplay of TR post-translational modification with TR localization: palmitoylation directs p30 to the membrane; phosphorylation promotes nuclear retention; acetylation occurs within the hinge NLS-1 and ubiquitination and sumoylation occur within the NES-containing LBD of TR. Although not yet reported to be post-translationally modified, TR $\alpha 1$ p43 contains mitochondrial import sequences and thus has a high probability of also containing PTM sites that modulate trafficking.

\section{Mislocalization of thyroid hormone receptors and disease}

In addition to diseases correlated with dysregulated hormone production, mutations in TR can give rise to disease, most notably the autosomal dominant resistance to thyroid hormone (RTH) syndrome; and mutations can contribute to certain types of cancer, including human hepatocellular carcinoma, renal clear cell carcinoma, breast cancer, pituitary tumor and thyroid cancer (Astapova et al. 2011). Early evidence to suggest that mutated TR could be involved in carcinogenesis came from the discovery that TR $\alpha 1$ is the cellular counterpart of the retroviral $\mathrm{v}$-ErbA carried by the avian erythroblastosis virus involved in acute erythroleukemia and sarcomas (Sap et al. 1986). Many of these TR mutants have lost $\mathrm{T}_{3}$ binding and transactivation capacity and some exhibit dominant negative activity (Conde et al. 2006, Martinez-Iglesias et al. 2009, Rosen \& Privalsky 2009, 2011, Chan \& Privalsky 2010, Rosen et al. 2011, Kim \& Cheng 2013, Lin et al. 2013, Wojcicka et al. 2014). The question is thus raised, does receptor localization impact disease pathology? So far, the answer appears to be, yes. Dominant negative TR mutants, such as v-ErbA, have been shown to localize to both the nuclear and cytoplasmic compartments in cells (Boucher et al. 1988), are recruited to aggresomes, display altered transport activity and mislocalize TR $\alpha 1$ to these cytosolic inclusions (Bunn et al. 2001, DeLong et al. 2004, Bonamy et al. 2005, Bonamy \& Allison 2006, Bondzi et al. 2011, Takalo et al. 2013, Zhang et al. 2018). The altered localization of v-ErbA appears to be enhanced by acquisition of the N-terminal viral Gag sequence, which harbors a strong CRM1-dependent NES (DeLong et al. 2004).

The factors that determine whether a given amino acid substitution causes endocrine disruption or cancer remain enigmatic, particularly for changes within the LBD. Typically, human cancers have multiple TR mutations, while single mutations are characteristic of $\mathrm{RTH}$, and it has been proposed that synergistic interactions of these mutations strengthen the dominant negative activity (Rosen \& Privalsky 2009, 2011). RTH syndromes exist due to mutations in the respective TR isoforms, TR $\alpha 1$ and TR $\beta 1$, and the variability in symptomatic phenotype is characterized by the tissues in which these isoforms are highly expressed (Mullur et al. 2014, Vella et al. 2014, Mendoza \& Hollenberg 2017, Vella $\&$ Hollenberg 2017). Clinical phenotypes of RTH include elevated thyroid hormone levels, goiter, short stature, decreased weight, tachycardia, hearing loss, attentiondeficit hyperactivity disorder, decreased IQ and dyslexia (Parrilla et al. 1991, Bochukova et al. 2012, Dumitrescu \& Refetoff 2013, Moran et al. 2013, Schoenmakers et al. 2013). Interestingly, the highest frequency of mutations occurs in the region corresponding to NES-H12, with another cluster of mutations occurring within NES-H3/H6 (Fig. 1).

Except for our prior studies, there is little information on the contribution of altered nucleocytoplasmic shuttling dynamics to the phenotype of RTH and cancerpromoting mutants. Two of our recent findings stand out: a R26H substitution in NLS-2 of the oncoprotein v-ErbA abrogates the activity of NLS-2, while mutagenesis studies on NES-H12 point to the intriguing possibility that altered shuttling of TR $\beta 1$ may be a contributing factor in RTH (Mavinakere et al. 2012). Based on these data, we hypothesize that intracellular mislocalization of TR is a crucial factor to consider in pathogenesis (Bonamy et al. 2005, Bonamy \& Allison 2006).

\section{Concluding remarks}

Thyroid hormone receptor subtypes mediate the actions of thyroid hormone in a variety of cellular compartments, including the nucleus, the mitochondria and at the inner surface of the plasma membrane (Fig. 4). Within the nucleus, TR $\alpha 1$ and TR $\beta 1$ bind to the TREs of target genes, in the presence or absence of thyroid hormone, to influence an astonishing number of cellular processes, 
including cell proliferation, oxygen consumption, protein synthesis and carbohydrate, lipid and vitamin metabolism. The physiological significance of TR $\alpha 1$ and TR $\beta 1$ nucleocytoplasmic shuttling may, at least in part, be to serve as a 'ferry boat' (Kolodkin et al. 2010) to increase the rate of $\mathrm{T}_{3}$ (and possibly $\mathrm{T}_{4}$ ) nuclear entry, relative to simple diffusion through the cytosol, or to circumvent localization of $\mathrm{T}_{3}$ to the mitochondria. Furthermore, important PTMs have been reported that suggest an increasingly complex interplay with TR's NLS and NES motifs, and possibly MIS motifs, which may affect TR's ultimate localization in target tissues. There is a dynamic balance between nuclear import, retention and export of shuttling transcription factors and, in the case of TR, localization to cytoplasmic compartments as well. These observations, coupled with the multiplicity of thyroid hormone signaling within the cell, may provide important insights into the development of treatments for RTH and some types of cancer.

\section{Declaration of interest}

The authors declare that there is no conflict of interest that could be perceived as prejudicing the impartiality of this review.

\section{Funding}

This work was supported in part by National Institutes of Health grant 2R15DK058028 and National Science Foundation grant MCB 1120513 to LA A.

\section{References}

Abdel-Hafiz HA \& Horwitz KB 2014 Post-translational modifications of the progesterone receptors. Journal of Steroid Biochemistry and Molecular Biology 140 80-89. (https://doi.org/10.1016/j.jsbmb.2013.12.008)

Abe S, Namba N, Abe M, Fujiwara M, Aikawa T, Kogo M \& Ozono K 2012 Monocarboxylate transporter 10 functions as a thyroid hormone transporter in chondrocytes. Endocrinology 153 4049-4058. (https:// doi.org/10.1210/en.2011-1713)

Andersson ML \& Vennstrom B 1997 Chicken thyroid hormone receptor $\alpha$ requires the $\mathrm{N}$-terminal amino acids for exclusive nuclear localization. FEBS Letters 416 291-296. (https://doi.org/10.1016/ S0014-5793(97)01223-4)

Astapova I \& Hollenberg AN 2013 The in vivo role of nuclear receptor corepressors in thyroid hormone action. Biochimica et Biophysica Acta 1830 3876-3881. (https://doi.org/10.1016/j.bbagen.2012.07.001)

Astapova I, Vella KR, Ramadoss P, Holtz KA, Rodwin BA, Liao XH, Weiss RE, Rosenberg MA, Rosenzweig A \& Hollenberg AN 2011 The nuclear receptor corepressor (NCoR) controls thyroid hormone sensitivity and the set point of the hypothalamic-pituitary-thyroid axis. Molecular Endocrinology 25 212-224. (https://doi.org/10.1210/ me.2010-0462)

Ayers S, Switnicki MP, Angajala A, Lammel J, Arumanayagam AS \& Webb P 2014 Genome-wide binding patterns of thyroid hormone receptor beta. PLOS ONE 9 e81186. (https://doi.org/10.1371/journal. pone.0081186)

Azevedo C \& Saiardi A 2016 Why always lysine? The ongoing tale of one of the most modified amino acids. Advances in Biological Regulation 60 144-150. (https://doi.org/10.1016/j.jbior.2015.09.008)

Bassett JH, Harvey CB \& Williams GR 2003 Mechanisms of thyroid hormone receptor-specific nuclear and extra nuclear actions. Molecular and Cellular Endocrinology 213 1-11. (https://doi. org/10.1016/j.mce.2003.10.033)

Baumann CT, Maruvada P, Hager GL \& Yen PM 2001 Nuclear cytoplasmic shuttling by thyroid hormone receptors. Journal of Biological Chemistry 276 11237-11245. (https://doi.org/10.1074/jbc.M011112200)

Bernal J 2017 Thyroid hormone regulated genes in cerebral cortex development. Journal of Endocrinology 232 R83-R97. (https://doi. org/10.1530/JOE-16-0424)

Bernal J \& Morte B 2013 Thyroid hormone receptor activity in the absence of ligand: physiological and developmental implications. Biochimica et Biophysica Acta 1830 3893-3899. (https://doi. org/10.1016/j.bbagen.2012.04.014)

Bernal J, Guadano-Ferraz A \& Morte B 2015 Thyroid hormone transporters--functions and clinical implications. Nature Reviews Endocrinology 11 406-417. (https://doi.org/10.1038/nrendo.2015.66)

Bishop CM, McCabe CJ, Gittoes NJ, Butler PJ \& Franklyn JA 2000 Tissuespecific regulation of thyroid hormone receptor mRNA isoforms and target gene proteins in domestic ducks. Journal of Endocrinology 165 607-615. (https://doi.org/10.1677/joe.0.1650607)

Bochukova E, Schoenmakers N, Agostini M, Schoenmakers E, Rajanayagam O, Keogh JM, Henning E, Reinemund J, Gevers E, Sarri M, et al. 2012 A mutation in the thyroid hormone receptor $\alpha$ gene. New England Journal of Medicine 366 243-249. (https://doi. org/10.1056/NEJMoa1110296)

Bonaldi T, Talamo F, Scaffidi P, Ferrera D, Porto A, Bachi A, Rubartelli A, Agresti A \& Bianchi ME 2003 Monocytic cells hyperacetylate chromatin protein HMGB1 to redirect it towards secretion. EMBO Journal 22 5551-5560. (https://doi.org/10.1093/emboj/cdg516)

Bonamy GM \& Allison LA 2006 Oncogenic conversion of the thyroid hormone receptor by altered nuclear transport. Nuclear Receptor Signaling 4 e008. (https://doi.org/10.1621/nrs.04008)

Bonamy GM, Guiochon-Mantel A \& Allison LA 2005 Cancer promoted by the oncoprotein v-ErbA may be due to subcellular mislocalization of nuclear receptors. Molecular Endocrinology 19 1213-1230. (https:// doi.org/10.1210/me.2004-0204)

Bondzi C, Brunner AM, Munyikwa MR, Connor CD, Simmons AN, Stephens SL, Belt PA, Roggero VR, Mavinakere MS, Hinton SD, et al. 2011 Recruitment of the oncoprotein v-ErbA to aggresomes. Molecular and Cellular Endocrinology 332 196-212. (https://doi.org/10.1016/j. mce.2010.10.012)

Boucher P, Koning A \& Privalsky ML 1988 The avian erythroblastosis virus erbA oncogene encodes a DNA-binding protein exhibiting distinct nuclear and cytoplasmic subcellular localizations. Journal of Virology 62 534-544.

Brent GA 2012 Mechanisms of thyroid hormone action. Journal of Clinical Investigation 122 3035-3043. (https://doi.org/10.1172/JCI60047)

Buchholz DR, Paul BD, Fu L \& Shi YB 2006 Molecular and developmental analyses of thyroid hormone receptor function in Xenopus laevis, the African clawed frog. General and Comparative Endocrinology 145 1-19. (https://doi.org/10.1016/j.ygcen.2005.07.009)

Bunn CF, Neidig JA, Freidinger KE, Stankiewicz TA, Weaver BS, McGrew J \& Allison LA 2001 Nucleocytoplasmic shuttling of the thyroid hormone receptor $\alpha$. Molecular Endocrinology 15 512-533. (https://doi. $\operatorname{org} / 10.1210 /$ mend.15.4.0619)

Carazo A, Levin J, Casas F, Seyer P, Grandemange S, Busson M, Pessemesse L, Wrutniak-Cabello C \& Cabello G 2012 Protein sequences involved in the mitochondrial import of the 3,5,3'-L-triiodothyronine receptor p43. Journal of Cellular Physiology 227 3768-3777. (https://doi.org/10.1002/jcp.24085) 
Casas F, Busson M, Grandemange S, Seyer P, Carazo A, Pessemesse L, Wrutniak-Cabello C \& Cabello G 2006 Characterization of a novel thyroid hormone receptor $\alpha$ variant involved in the regulation of myoblast differentiation. Molecular Endocrinology 20 749-763. (https:// doi.org/10.1210/me.2005-0074)

Cautain B, Hill R, de Pedro N \& Link W 2015 Components and regulation of nuclear transport processes. FEBS Journal 282 445-462. (https://doi. org/10.1111/febs.13163)

Chan IH \& Privalsky ML 2010 A conserved lysine in the thyroid hormone receptor- $\alpha 1$ DNA-binding domain, mutated in hepatocellular carcinoma, serves as a sensor for transcriptional regulation. Molecular Cancer Research 8 15-23. (https://doi.org/10.1158/1541-7786.MCR-09-0425)

Chassande O, Fraichard A, Gauthier K, Flamant F, Legrand C, Savatier P, Laudet V Samarut J 1997 Identification of transcripts initiated from an internal promoter in the c-erbA alpha locus that encode inhibitors of retinoic acid receptor-alpha and triiodothyronine receptor activities. Molecular Endocrinology 11 1278-1290. (https://doi. org/10.1210/mend.11.9.9972)

Chatonnet F, Guyot R, Benoit G \& Flamant F 2013 Genome-wide analysis of thyroid hormone receptors shared and specific functions in neural cells. PNAS 110 E766-E775. (https://doi.org/10.1073/ pnas.1210626110)

Chen CY, Tsai MM, Chi HC \& Lin KH 2013 Biological significance of a thyroid hormone-regulated secretome. Biochimica et Biophysica Acta 1834 2271-2284. (https://doi.org/10.1016/j.bbapap.2013.02.016)

Chook YM \& Suel KE 2011 Nuclear import by karyopherin- $\beta$ s: recognition and inhibition. Biochimica et Biophysica Acta 1813 1593-1606. (https://doi.org/10.1016/j.bbamcr.2010.10.014)

Conde I, Paniagua R, Zamora J, Blanquez MJ, Fraile B, Ruiz A \& Arenas MI 2006 Influence of thyroid hormone receptors on breast cancer cell proliferation. Annals of Oncology 17 60-64. (https://doi.org/10.1093/ annonc/mdj040)

Cui Y, Zhang M, Pestell R, Curran EM, Welshons WV \& Fuqua SA 2004 Phosphorylation of estrogen receptor $\alpha$ blocks its acetylation and regulates estrogen sensitivity. Cancer Research 64 9199-9208. (https:// doi.org/10.1158/0008-5472.CAN-04-2126)

Cvoro A, Bajic A, Zhang A, Simon M, Golic I, Sieglaff DH, MaleticSavatic M, Korac A \& Webb P 2016 Ligand independent and subtypeselective actions of thyroid hormone receptors in human adipose derived stem cells. PLOS ONE 11 e0164407. (https://doi.org/10.1371/ journal.pone.0164407)

Dai J, Bercury KK, Jin W \& Macklin WB 2015 Olig1 acetylation and nuclear export mediate oligodendrocyte development. Journal of Neuroscience 35 15875-15893. (https://doi.org/10.1523/ JNEUROSCI.0882-15.2015)

Darras VM, Van Herck SL, Heijlen M \& De Groef B 2011 Thyroid hormone receptors in two model species for vertebrate embryonic development: chicken and zebrafish. Journal of Thyroid Research $\mathbf{2 0 1 1}$ 402320. (https://doi.org/10.4061/2011/402320)

Dasgupta S \& O'Malley BW 2014 Transcriptional coregulators: emerging roles of SRC family of coactivators in disease pathology. Journal of Molecular Endocrinology 53 R47-R59. (https://doi.org/10.1530/JME-140080)

Davis PJ, Goglia F \& Leonard JL 2016 Nongenomic actions of thyroid hormone. Nature Reviews Endocrinology 12 111-121. (https://doi. org/10.1038/nrendo.2015.205)

DeLong LJ, Bonamy GM, Fink EN \& Allison LA 2004 Nuclear export of the oncoprotein $\mathrm{v}$-ErbA is mediated by acquisition of a viral nuclear export sequence. Journal of Biological Chemistry 279 15356-15367. (https://doi.org/10.1074/jbc.M308214200)

Dentice M, Marsili A, Zavacki A, Larsen PR \& Salvatore D 2013 The deiodinases and the control of intracellular thyroid hormone signaling during cellular differentiation. Biochimica et Biophysica Acta 1830 3937-3945. (https://doi.org/10.1016/j.bbagen.2012.05.007)

Diallo EM, Wilhelm KG Jr, Thompson DL \& Koenig RJ 2007 Variable RXR requirements for thyroid hormone responsiveness of endogenous genes. Molecular and Cellular Endocrinology 264 149-156. (https://doi. org/10.1016/j.mce.2006.11.004)

Drazic A, Myklebust LM, Ree R \& Arnesen T 2016 The world of protein acetylation. Biochimica et Biophysica Acta 1864 1372-1401. (https:// doi.org/10.1016/j.bbapap.2016.06.007)

Dumitrescu AM \& Refetoff S 2013 The syndromes of reduced sensitivity to thyroid hormone. Biochimica et Biophysica Acta 1830 3987-4003. (https://doi.org/10.1016/j.bbagen.2012.08.005)

Faresse N 2014 Post-translational modifications of the mineralocorticoid receptor: how to dress the receptor according to the circumstances? Journal of Steroid Biochemistry and Molecular Biology 143 334-342. (https://doi.org/10.1016/j.jsbmb.2014.04.015)

Fernandez-Majada V, Pujadas J, Vilardell F, Capella G, Mayo MW, Bigas A \& Espinosa L 2007 Aberrant cytoplasmic localization of N-CoR in colorectal tumors. Cell Cycle 6 1748-1752. (https://doi.org/10.4161/cc.6.14.4429)

Figueira AC, Saidemberg DM, Souza PC, Martinez L, Scanlan TS, Baxter JD, Skaf MS, Palma MS, Webb P \& Polikarpov I 2011 Analysis of agonist and antagonist effects on thyroid hormone receptor conformation by hydrogen/deuterium exchange. Molecular Endocrinology 25 15-31. (https://doi.org/10.1210/me.2010-0202)

Flamant F 2016 Futures challenges in thyroid hormone signaling research. Frontiers in Endocrinology 7 58. (https://doi.org/10.3389/ fendo.2016.00058)

Flamant F \& Gauthier K 2013 Thyroid hormone receptors: the challenge of elucidating isotype-specific functions and cell-specific response. Biochimica et Biophysica Acta 1830 3900-3907. (https://doi. org/10.1016/j.bbagen.2012.06.003)

Flamant F, Cheng SY, Hollenberg AN, Moeller LC, Samarut J, Wondisford FE, Yen PM \& Refetoff S 2017 Thyroid hormone signaling pathways: time for a more precise nomenclature. Endocrinology 158 2052-2057. (https://doi.org/10.1210/en.2017-00250)

Flamini MI, Uzair ID, Pennacchio GE, Neira FJ, Mondaca JM, CuelloCarrion FD, Jahn GA, Simoncini T \& Sanchez AM 2017 Thyroid hormone controls breast cancer cell movement via integrin $\alpha \mathrm{V} / \beta 3$ / SRC/FAK/PI3-Kinases. Hormones and Cancer 8 16-27. (https://doi. org/10.1007/s12672-016-0280-3)

Fumel B, Roy S, Fouchecourt S, Livera G, Parent AS, Casas F \& Guillou F 2013 Depletion of the p43 mitochondrial T3 receptor increases Sertoli cell proliferation in mice. PLOS ONE 8 e74015. (https://doi. org/10.1371/journal.pone.0074015)

Galay-Burgos M, Power DM, Llewellyn L \& Sweeney GE 2008 Thyroid hormone receptor expression during metamorphosis of Atlantic halibut (Hippoglossus hippoglossus). Molecular and Cellular Endocrinology 281 56-63. (https://doi.org/10.1016/j.mce.2007.10.009)

Galton VA 2017 The ups and downs of the thyroxine pro-hormone hypothesis. Molecular and Cellular Endocrinology 458 105-111. (https:// doi.org/10.1016/j.mce.2017.01.029)

Grespin ME, Bonamy GM, Roggero VR, Cameron NG, Adam LE, Atchison AP, Fratto VM \& Allison LA 2008 Thyroid hormone receptor $\alpha 1$ follows a cooperative CRM1/calreticulin-mediated nuclear export pathway. Journal of Biological Chemistry 283 25576-25588. (https:// doi.org/10.1074/jbc.M710482200)

Grontved L, Waterfall JJ, Kim DW, Baek S, Sung MH, Zhao L, Park JW, Nielsen R, Walker RL, Zhu YJ, et al. 2015 Transcriptional activation by the thyroid hormone receptor through ligand-dependent receptor recruitment and chromatin remodelling. Nature Communications 6 7048. (https://doi.org/10.1038/ncomms8048)

Guissouma H, Ghaddab-Zroud R, Seugnet I, Decherf S, Demeneix B \& Clerget-Froidevaux MS 2014 TR $\alpha 2$ exerts dominant negative effects on hypothalamic Trh transcription in vivo. PLOS ONE 9 e95064. (https://doi.org/10.1371/journal.pone.0095064)

Hahm JB \& Privalsky ML 2013 Research resource: identification of novel coregulators specific for thyroid hormone receptor- $\beta 2$. Molecular Endocrinology 27 840-859. (https://doi.org/10.1210/me.2012-1117)

Hayama R, Rout MP \& Fernandez-Martinez J 2017 The nuclear pore complex core scaffold and permeability barrier: variations of a
(C) 2018 Society for Endocrinology Published by Bioscientifica Ltd. 
common theme. Current Opinion in Cell Biology 46 110-118. (https:// doi.org/10.1016/i.ceb.2017.05.003)

Hayer A, Stoeber M, Bissig C \& Helenius A 2010 Biogenesis of caveolae: stepwise assembly of large caveolin and cavin complexes. Traffic $\mathbf{1 1}$ 361-382. (https://doi.org/10.1111/j.1600-0854.2009.01023.x)

Helbing CC, Crump K, Bailey CM, Kohno S, Veldhoen N, Bryan T, Bermudez D \& Guillette LJ Jr 2006 Isolation of the alligator (Alligator mississippiensis) thyroid hormone receptor $\alpha$ and $\beta$ transcripts and their responsiveness to thyroid stimulating hormone. General and Comparative Endocrinology 149 141-150. (https://doi.org/10.1016/j. ygcen.2006.05.019)

Hiroi Y, Kim HH, Ying H, Furuya F, Huang Z, Simoncini T, Noma K, Ueki K, Nguyen NH, Scanlan TS, et al. 2006 Rapid nongenomic actions of thyroid hormone. PNAS 103 14104-14109. (https://doi. org/10.1073/pnas.0601600103)

Huang W, Xu F, Qu T, Zhang R, Li L, Que H \& Zhang G 2015 Identification of thyroid hormones and functional characterization of thyroid hormone receptor in the Pacific Oyster Crassostrea gigas provide insight into evolution of the thyroid hormone system. PLoS ONE 10 e0144991. (https://doi.org/10.1371/journal. pone.0144991)

Kalyanaraman H, Schwappacher R, Joshua J, Zhuang S, Scott BT, Klos M, Casteel DE, Frangos JA, Dillmann W, Boss GR, et al. 2014 Nongenomic thyroid hormone signaling occurs through a plasma membrane-localized receptor. Science Signaling 7 ra48. (https://doi. org/10.1126/scisignal.2004911)

Kanaho YI, Endo D \& Park MK 2006 Molecular characterization of thyroid hormone receptors from the leopard gecko, and their differential expression in the skin. Zoological Science 23 549-556. (https://doi.org/10.2108/zsj.23.549)

Kim WG \& Cheng SY 2013 Thyroid hormone receptors and cancer. Biochimica et Biophysica Acta 1830 3928-3936. (https://doi. org/10.1016/j.bbagen.2012.04.002)

Kimura M \& Imamoto N 2014 Biological significance of the importin- $\beta$ family-dependent nucleocytoplasmic transport pathways. Traffic $\mathbf{1 5}$ 727-748. (https://doi.org/10.1111/tra.12174)

Kolodkin AN, Bruggeman FJ, Plant N, Mone MJ, Bakker BM, Campbell MJ, van Leeuwen JP, Carlberg C, Snoep JL \& Westerhoff HV 2010 Design principles of nuclear receptor signaling: how complex networking improves signal transduction. Molecular Systems Biology 6 446. (https://doi.org/10.1038/msb.2010.102)

Kumara-Siri MH, Shapiro LE \& Surks MI 1986 Association of the 3,5,3'-triiodo-L-thyronine nuclear receptor with the nuclear matrix of cultured growth hormone-producing rat pituitary tumor cells (GC cells). Journal of Biological Chemistry $2612844-2852$.

Laudet V \& Gronemeyer H 2002 The Nuclear Receptor: Factsbook. San Diego, CA, USA: Academic Press.

Lee Y \& Mahdavi V 1993 The D domain of the thyroid hormone receptor $\alpha 1$ specifies positive and negative transcriptional regulation functions. Journal of Biological Chemistry 268 2021-2028.

Leonard JL \& Farwell AP 1997 Thyroid hormone-regulated actin polymerization in brain. Thyroid 7 147-151. (https://doi.org/10.1089/ thy.1997.7.147)

Li C, Goryaynov A \& Yang W 2016 The selective permeability barrier in the nuclear pore complex. Nucleus 7 430-446. (https://doi.org/10.108 0/19491034.2016.1238997)

Lin HY, Hopkins R, Cao HJ, Tang HY, Alexander C, Davis FB \& Davis PJ 2005 Acetylation of nuclear hormone receptor superfamily members: thyroid hormone causes acetylation of its own receptor by a mitogenactivated protein kinase-dependent mechanism. Steroids 70 444-449. (https://doi.org/10.1016/j.steroids.2005.03.001)

Lin YH, Liao CJ, Huang YH, Wu MH, Chi HC, Wu SM, Chen CY, Tseng YH, Tsai CY, Chung IH, et al. 2013 Thyroid hormone receptor represses miR-17 expression to enhance tumor metastasis in human hepatoma cells. Oncogene 32 4509-4518. (https://doi.org/10.1038/ onc.2013.309)
Lin W, Gao L \& Chen X 2015 Protein-specific imaging of posttranslational modifications. Current Opinion in Chemical Biology 28 156-163. (https://doi.org/10.1016/j.cbpa.2015.07.020)

Lin HY, Chin YT, Yang YC, Lai HY, Wang-Peng J, Liu LF, Tang HY \& Davis PJ 2016 Thyroid hormone, cancer, and apoptosis. Comprehensive Physiology 6 1221-1237. (https://doi.org/10.1002/cphy.c150035)

Liu YY, Kogai T, Schultz JJ, Mody K \& Brent GA 2012 Thyroid hormone receptor isoform-specific modification by small ubiquitin-like modifier (SUMO) modulates thyroid hormone-dependent gene regulation. Journal of Biological Chemistry 287 36499-36508. (https:// doi.org/10.1074/jbc.M112.344317)

Liu YY, Ayers S, Milanesi A, Teng X, Rabi S, Akiba Y \& Brent GA 2015 Thyroid hormone receptor sumoylation is required for preadipocyte differentiation and proliferation. Journal of Biological Chemistry 290 7402-7415. (https://doi.org/10.1074/jbc.M114.600312)

Lu B, Antoine DJ, Kwan K, Lundback P, Wahamaa H, Schierbeck H, Robinson M, Van Zoelen MA, Yang H, Li J, et al. 2014 JAK/STAT1 signaling promotes HMGB1 hyperacetylation and nuclear translocation. PNAS 111 3068-3073. (https://doi.org/10.1073/pnas.1316925111)

Macchia E, Falcone M, Giorgilli G, Bogazzi F, Antonangeli L, Baccarini S, Fontanini G, Torresani J, DeGroot LJ \& Pinchera A 1992 Site-specific anti-c-erb A antibodies recognizing native thyroid hormone receptors: their use to detect the expression and localization of $\alpha$ and $\beta$ c-erb A proteins in rat liver. Journal of Receptor Research 12 201-215. (https:// doi.org/10.3109/10799899209074792)

Manzon LA, Youson JH, Holzer G, Staiano L, Laudet V \& Manzon RG 2014 Thyroid hormone and retinoid $\mathrm{X}$ receptor function and expression during sea lamprey (Petromyzon marinus) metamorphosis. General and Comparative Endocrinology 204 211-222. (https://doi. org/10.1016/j.ygcen.2014.05.030)

Martin NP, Marron Fernandez de Velasco E, Mizuno F, Scappini EL, Gloss B, Erxleben C, Williams JG, Stapleton HM, Gentile S \& Armstrong DL 2014 A rapid cytoplasmic mechanism for PI3 kinase regulation by the nuclear thyroid hormone receptor, TR $\beta$, and genetic evidence for its role in the maturation of mouse hippocampal synapses in vivo. Endocrinology 155 3713-3724. (https://doi. org/10.1210/en.2013-2058)

Martinez-Iglesias O, Garcia-Silva S, Tenbaum SP, Regadera J, Larcher F, Paramio JM, Vennstrom B \& Aranda A 2009 Thyroid hormone receptor $\beta 1$ acts as a potent suppressor of tumor invasiveness and metastasis. Cancer Research 69 501-509. (https://doi. org/10.1158/0008-5472.CAN-08-2198)

Martinez L, Webb P, Polikarpov I \& Skaf MS 2006 Molecular dynamics simulations of ligand dissociation from thyroid hormone receptors: evidence of the likeliest escape pathway and its implications for the design of novel ligands. Journal of Medicinal Chemistry 49 23-26. (https://doi.org/10.1021/jm050805n)

Maruvada P, Baumann CT, Hager GL \& Yen PM 2003 Dynamic shuttling and intranuclear mobility of nuclear hormone receptors. Journal of Biological Chemistry 278 12425-12432. (https://doi.org/10.1074/jbc. M202752200)

Mavinakere MS, Powers JM, Subramanian KS, Roggero VR \& Allison LA 2012 Multiple novel signals mediate thyroid hormone receptor nuclear import and export. Journal of Biological Chemistry $\mathbf{2 8 7}$ 31280-31297. (https://doi.org/10.1074/jbc.M112.397745)

McKenna NJ, Lanz RB \& O’Malley BW 1999 Nuclear receptor coregulators: cellular and molecular biology. Endocrine Reviews 20 321-344. (https://doi.org/10.1210/edrv.20.3.0366)

Medici M, Visser WE, Visser TJ \& Peeters RP 2015 Genetic determination of the hypothalamic-pituitary-thyroid axis: where do we stand? Endocrine Reviews 36 214-244. (https://doi.org/10.1210/er.2014-1081)

Mendoza A \& Hollenberg AN 2017 New insights into thyroid hormone action. Pharmacology and Therapeutics 173 135-145. (https://doi. org/10.1016/j.pharmthera.2017.02.012)

Mendoza A, Astapova I, Shimizu H, Gallop MR, Al-Sowaimel L, MacGowan SMD, Bergmann T, Berg AH, Tenen DE, Jacobs C, et al. 
2017 NCoR1-independent mechanism plays a role in the action of the unliganded thyroid hormone receptor. PNAS 114 E8458-E8467. (https://doi.org/10.1073/pnas.1706917114)

Mondal S, Raja K, Schweizer U \& Mugesh G 2016 Chemistry and biology in the biosynthesis and action of thyroid hormones. Angewandte Chemie International Edition in English 55 7606-7630. (https://doi. org/10.1002/anie.201601116)

Moran C, Schoenmakers N, Agostini M, Schoenmakers E, Offiah A, Kydd A, Kahaly G, Mohr-Kahaly S, Rajanayagam O, Lyons G, et al. 2013 An adult female with resistance to thyroid hormone mediated by defective thyroid hormone receptor alpha. Journal of Clinical Endocrinology and Metabolism 98 4254-4261. (https://doi.org/10.1210/ jc.2013-2215)

Moras D \& Gronemeyer H 1998 The nuclear receptor ligand-binding domain: structure and function. Current Opinion in Cell Biology $\mathbf{1 0}$ 384-391. (https://doi.org/10.1016/S0955-0674(98)80015-X)

Moriyama K, Yamamoto H, Futawaka K, Atake A, Kasahara M \& Tagami T 2016 Molecular characterization of human thyroid hormone receptor $\beta$ isoform 4. Endocrine Research 41 34-42. (https://doi.org/10.3109/074 35800.2015.1066801)

Morte B \& Bernal J 2014 Thyroid hormone action: astrocyte-neuron communication. Frontiers in Endocrinology 5 82. (https://doi. org/10.3389/fendo.2014.00082)

Mullur R, Liu YY \& Brent GA 2014 Thyroid hormone regulation of metabolism. Physiological Reviews 94 355-382. (https://doi. org/10.1152/physrev.00030.2013)

Nascimento AS, Dias SM, Nunes FM, Aparicio R, Ambrosio AL, Bleicher L, Figueira AC, Santos MA, de Oliveira Neto M, Fischer H, et al. 2006 Structural rearrangements in the thyroid hormone receptor hinge domain and their putative role in the receptor function. Journal of Molecular Biology 360 586-598. (https://doi.org/10.1016/j. jmb.2006.05.008)

Nelson ER \& Habibi HR 2008 Functional significance of a truncated thyroid receptor subtype lacking a hormone-binding domain in goldfish. Endocrinology 149 4702-4709. (https://doi.org/10.1210/ en.2008-0107)

Nicoll JB, Gwinn BL, Iwig JS, Garcia PP, Bunn CF \& Allison LA 2003 Compartment-specific phosphorylation of rat thyroid hormone receptor $\alpha 1$ regulates nuclear localization and retention. Molecular and Cellular Endocrinology 205 65-77. (https://doi.org/10.1016/S03037207(03)00199-0)

Oberoi J, Fairall L, Watson PJ, Yang JC, Czimmerer Z, Kampmann T, Goult BT, Greenwood JA, Gooch JT, Kallenberger BC, et al. 2011 Structural basis for the assembly of the SMRT/NCoR core transcriptional repression machinery. Nature Structural and Molecular Biology 18 177-184. (https://doi.org/10.1038/nsmb.1983)

Oberste-Berghaus C, Zanger K, Hashimoto K, Cohen RN, Hollenberg AN \& Wondisford FE 2000 Thyroid hormone-independent interaction between the thyroid hormone receptor $\beta 2$ amino terminus and coactivators. Journal of Biological Chemistry 275 1787-1792. (https:// doi.org/10.1074/jbc.275.3.1787)

Orozco A, Navarrete-Ramirez P, Olvera A \& Garcia GC 2014 3,5-Diiodothyronine (T2) is on a role. A new hormone in search of recognition. General and Comparative Endocrinology 203 174-180. (https://doi.org/10.1016/j.ygcen.2014.02.014)

Panayiotou R, Miralles F, Pawlowski R, Diring J, Flynn HR, Skehel M \& Treisman R 2016 Phosphorylation acts positively and negatively to regulate MRTF-A subcellular localisation and activity. eLife 5 e15460. (https://doi.org/10.7554/eLife.15460)

Pappa T, Ferrara AM \& Refetoff S 2015 Inherited defects of thyroxinebinding proteins. Best Practice and Research: Clinical Endocrinology and Metabolism 29 735-747. (https://doi.org/10.1016/j.beem.2015.09.002)

Parrilla R, Mixson AJ, McPherson JA, McClaskey JH \& Weintraub BD 1991 Characterization of seven novel mutations of the c-erbA beta gene in unrelated kindreds with generalized thyroid hormone resistance. Evidence for two "hot spot" regions of the ligand binding domain. Journal of Clinical Investigation 88 2123-2130. (https://doi. org/10.1172/JCI115542)

Pascual A \& Aranda A 2013 Thyroid hormone receptors, cell growth and differentiation. Biochimica et Biophysica Acta 1830 3908-3916. (https://doi.org/10.1016/j.bbagen.2012.03.012)

Pawlak M, Lefebvre P \& Staels B 2012 General molecular biology and architecture of nuclear receptors. Current Topics in Medicinal Chemistry 12 486-504. (https://doi.org/10.2174/156802612799436641)

Politis SN, Servili A, Mazurais D, Zambonino-Infante JL, Miest JJ, Tomkiewicz J \& Butts IAE 2018 Temperature induced variation in gene expression of thyroid hormone receptors and deiodinases of European eel (Anguilla anguilla) larvae. General and Comparative Endocrinology 259 54-65. (https://doi.org/10.1016/j.ygcen.2017.11.003)

Psarra AM \& Sekeris CE 2008 Steroid and thyroid hormone receptors in mitochondria. IUBMB Life 60 210-223. (https://doi.org/10.1002/ iub.37)

Ramadoss P, Abraham BJ, Tsai L, Zhou Y, Costa-e-Sousa RH, Ye F, Bilban M, Zhao K \& Hollenberg AN 2014 Novel mechanism of positive versus negative regulation by thyroid hormone receptor $\beta 1$ (TR $\beta 1$ ) identified by genome-wide profiling of binding sites in mouse liver. Journal of Biological Chemistry 289 1313-1328. (https://doi. org/10.1074/jbc.M113.521450)

Rodriguez JA 2014 Interplay between nuclear transport and ubiquitin/ SUMO modifications in the regulation of cancer-related proteins. Seminars in Cancer Biology 27 11-19. (https://doi.org/10.1016/j. semcancer.2014.03.005)

Rodriguez JE, Liao JY, He J, Schisler JC, Newgard CB, Drujan D, Glass DJ Frederick CB, Yoder BC, Lalush DS, et al. 2015 The ubiquitin ligase MuRF1 regulates PPAR $\alpha$ activity in the heart by enhancing nuclear export via monoubiquitination. Molecular and Cellular Endocrinology 413 36-48. (https://doi.org/10.1016/j.mce.2015.06.008)

Roggero VR, Zhang J, Parente LE, Doshi Y, Dziedzic RC, McGregor EL, Varjabedian AD, Schad SE, Bondzi C \& Allison LA 2016 Nuclear import of the thyroid hormone receptor $\alpha 1$ is mediated by importin 7 , importin $\beta 1$, and adaptor importin $\alpha 1$. Molecular and Cellular Endocrinology 419 185-197. (https://doi.org/10.1016/j. mce.2015.10.016)

Rosen MD \& Privalsky ML 2009 Thyroid hormone receptor mutations found in renal clear cell carcinomas alter corepressor release and reveal helix 12 as key determinant of corepressor specificity. Molecular Endocrinology 23 1183-1192. (https://doi.org/10.1210/me.2009-0126)

Rosen MD \& Privalsky ML 2011 Thyroid hormone receptor mutations in cancer and resistance to thyroid hormone: perspective and prognosis. Journal of Thyroid Research 2011 361304. (https://doi. org/10.4061/2011/361304)

Rosen MD, Chan IH \& Privalsky ML 2011 Mutant thyroid hormone receptors (TRs) isolated from distinct cancer types display distinct target gene specificities: a unique regulatory repertoire associated with two renal clear cell carcinomas. Molecular Endocrinology 25 1311-1325. (https://doi.org/10.1210/me.2010-0420)

Ruiz-Llorente L, Martinez-Iglesias O, Garcia-Silva S, Tenbaum S, Regadera J \& Aranda A 2011 The thyroid hormone receptors as tumor suppressors. Hormone Molecular Biology and Clinical Investigation 5 79-89. (https://doi.org/10.1515/HMBCI.2010.045)

Saelim N, Holstein D, Chocron ES, Camacho P \& Lechleiter JD 2007 Inhibition of apoptotic potency by ligand stimulated thyroid hormone receptors located in mitochondria. Apoptosis 12 1781-1794. (https://doi.org/10.1007/s10495-007-0109-1)

Sanchez-Pacheco A, Martinez-Iglesias O, Mendez-Pertuz M \& Aranda A 2009 Residues K128, 132, and 134 in the thyroid hormone receptor- $\alpha$ are essential for receptor acetylation and activity. Endocrinology 150 5143-5152. (https://doi.org/10.1210/en.2009-0117)

Sap J, Munoz A, Damm K, Goldberg Y, Ghysdael J, Leutz A, Beug H \& Vennstrom B 1986 The c-erb-A protein is a high-affinity receptor for thyroid hormone. Nature 324 635-640. (https://doi. org/10.1038/324635a0)
() 2018 Society for Endocrinology Published by Bioscientifica Ltd. Printed in Great Britain 
Schoenmakers N, Moran C, Peeters RP, Visser T, Gurnell M \& Chatterjee K 2013 Resistance to thyroid hormone mediated by defective thyroid hormone receptor $\alpha$. Biochimica et Biophysica Acta $18304004-4008$. (https://doi.org/10.1016/j.bbagen.2013.03.018)

Schweizer U, Towell H, Vit A, Rodriguez-Ruiz A \& Steegborn C 2017 Structural aspects of thyroid hormone binding to proteins and competitive interactions with natural and synthetic compounds. Molecular and Cellular Endocrinology 458 57-67. (https://doi. org/10.1016/j.mce.2017.01.026)

Shimizu H, Astapova I, Ye F, Bilban M, Cohen RN \& Hollenberg AN 2015 NCoR1 and SMRT play unique roles in thyroid hormone action in vivo. Molecular and Cellular Biology 35 555-565. (https://doi. org/10.1128/MCB.01208-14)

Skah S, Uchuya-Castillo J, Sirakov M \& Plateroti M 2017 The thyroid hormone nuclear receptors and the Wnt/ $\beta$-catenin pathway: an intriguing liaison. Developmental Biology 422 71-82. (https://doi. org/10.1016/j.ydbio.2017.01.003)

Sonoda MT, Martinez L, Webb P, Skaf MS \& Polikarpov I 2008 Ligand dissociation from estrogen receptor is mediated by receptor dimerization: evidence from molecular dynamics simulations. Molecular Endocrinology 22 1565-1578. (https://doi.org/10.1210/me.2007-0501)

Soriano FX, Leveille F, Papadia S, Bell KF, Puddifoot C \& Hardingham GE 2011 Neuronal activity controls the antagonistic balance between peroxisome proliferator-activated receptor- $\gamma$ coactivator- $1 \alpha$ and silencing mediator of retinoic acid and thyroid hormone receptors in regulating antioxidant defenses. Antioxidants and Redox Signaling $\mathbf{1 4}$ 1425-1436. (https://doi.org/10.1089/ars.2010.3568)

Souza PC, Puhl AC, Martinez L, Aparicio R, Nascimento AS, Figueira AC, Nguyen P, Webb P, Skaf MS \& Polikarpov I 2014 Identification of a new hormone-binding site on the surface of thyroid hormone receptor. Molecular Endocrinology 28 534-545. (https://doi. org/10.1210/me.2013-1359)

Subramanian KS, Dziedzic RC, Nelson HN, Stern ME, Roggero VR, Bondzi C \& Allison LA 2015 Multiple exportins influence thyroid hormone receptor localization. Molecular and Cellular Endocrinology 411 86-96. (https://doi.org/10.1016/j.mce.2015.04.014)

Tagami T, Yamamoto H, Moriyama K, Sawai K, Usui T, Shimatsu A \& Naruse M 2010 Identification of a novel human thyroid hormone receptor $\beta$ isoform as a transcriptional modulator. Biochemical and Biophysical Research Communications 396 983-988. (https://doi. org/10.1016/j.bbrc.2010.05.038)

Takalo M, Salminen A, Soininen H, Hiltunen M \& Haapasalo A 2013 Protein aggregation and degradation mechanisms in neurodegenerative diseases. American Journal of Neurodegenerative Disease 2 1-14

Taylor E \& Heyland A 2017 Evolution of thyroid hormone signaling in animals: non-genomic and genomic modes of action. Molecular and Cellular Endocrinology 459 14-20. (https://doi.org/10.1016/j. mce.2017.05.019)

Tomura H, Lazar J, Phyillaier M \& Nikodem VM 1995 The N-terminal region (A/B) of rat thyroid hormone receptors $\alpha 1, \beta 1$, but not $\beta 2$ contains a strong thyroid hormone-dependent transactivation function. PNAS 92 5600-5604. (https://doi.org/10.1073/pnas.92.12.5600)

Tran EJ, King MC \& Corbett AH 2014 Macromolecular transport between the nucleus and the cytoplasm: advances in mechanism and emerging links to disease. Biochimica et Biophysica Acta 1843 2784-2795. (https://doi.org/10.1016/j.bbamcr.2014.08.003)
Umemoto T \& Fujiki Y 2012 Ligand-dependent nucleo-cytoplasmic shuttling of peroxisome proliferator-activated receptors, PPAR $\alpha$ and PPAR $\gamma$. Genes to Cells 17 576-596. (https://doi.org/10.1111/j.13652443.2012.01607.x)

van der Spek AH, Fliers E \& Boelen A 2017 Thyroid hormone metabolism in innate immune cells. Journal of Endocrinology 232 R67-R81. (https://doi.org/10.1530/JOE-16-0462)

Vella KR \& Hollenberg AN 2017 The actions of thyroid hormone signaling in the nucleus. Molecular and Cellular Endocrinology $\mathbf{4 5 8}$ 127-135. (https://doi.org/10.1016/j.mce.2017.03.001)

Vella KR, Ramadoss P, Costa ESRH, Astapova I, Ye FD, Holtz KA, Harris JC \& Hollenberg AN 2014 Thyroid hormone signaling in vivo requires a balance between coactivators and corepressors. Molecular and Cellular Biology 34 1564-1575. (https://doi.org/10.1128/MCB.00129-14)

Vennstrom B, Liu H \& Forrest D 2010 Thyroid hormone receptors. In Nuclear Receptors. Current Concepts and Future Challenges. Eds CM Bunce \& MJ Campbell. London, UK: Springer.

Wadosky KM, Berthiaume JM, Tang W, Zungu M, Portman MA, Gerdes AM \& Willis MS 2016 MuRF1 mono-ubiquitinates TR $\alpha$ to inhibit T3-induced cardiac hypertrophy in vivo. Journal of Molecular Endocrinology 56 273-290. (https://doi.org/10.1530/JME-15-0283)

Wang X \& Li S 2014 Protein mislocalization: mechanisms, functions and clinical applications in cancer. Biochimica et Biophysica Acta 1846 13-25. (https://doi.org/10.1016/j.bbcan.2014.03.006)

Weitzel JM 2016 Impaired repressor function in SUMOylation-defective thyroid hormone receptor isoforms. European Thyroid Journal 5 152-163. (https://doi.org/10.1159/000447232)

Williams GR 2000 Cloning and characterization of two novel thyroid hormone receptor $\beta$ isoforms. Molecular and Cellular Biology 20 8329-8342. (https://doi.org/10.1128/MCB.20.22.8329-8342.2000)

Wojcicka A, Piekielko-Witkowska A, Kedzierska H, Rybicka B, Poplawski P, Boguslawska J, Master A \& Nauman A 2014 Epigenetic regulation of thyroid hormone receptor $\beta$ in renal cancer. PLOS ONE 9 e97624. (https://doi.org/10.1371/journal.pone.0097624)

Wrutniak-Cabello C, Casas F \& Cabello G 2017 Mitochondrial T3 receptor and targets. Molecular and Cellular Endocrinology 458 112-120. (https://doi.org/10.1016/j.mce.2017.01.054)

Xu L, Glass CK \& Rosenfeld MG 1999 Coactivator and corepressor complexes in nuclear receptor function. Current Opinion in Genetics and Development 9 140-147. (https://doi.org/10.1016/S0959437X(99)80021-5)

Zhang J \& Lazar MA 2000 The mechanism of action of thyroid hormones. Annual Review of Physiology 62 439-466. (https://doi.org/10.1146/ annurev.physiol.62.1.439)

Zhang J, Roggero VR \& Allison LA 2018 Nuclear import and export of the thyroid hormone receptor. Vitamins and Hormones 106 45-66. (https://doi.org/10.1016/bs.vh.2017.04.002)

Zhao RL, Sun B, Liu Y, Li JH, Xiong WL, Liang DC, Guo G, Zuo AJ \& Zhang JY 2014 Cloning and identification of a novel thyroid hormone receptor $\beta$ isoform expressed in the pituitary gland. Molecular and Cellular Biochemistry 389 141-150. (https://doi. org/10.1007/s11010-013-1935-9)

Zhu XG, Hanover JA, Hager GL \& Cheng SY 1998 Hormone-induced translocation of thyroid hormone receptors in living cells visualized using a receptor green fluorescent protein chimera. Journal of Biological Chemistry 273 27058-27063. (https://doi.org/10.1074/ jbc.273.42.27058)

Received in final form 6 February 2018

Accepted 12 February 2018

Accepted Preprint published online 12 February 2018 http://joe.endocrinology-journals.org https://doi.org/10.1530/JOE-17-0708 (c) 2018 Society for Endocrinology Published by Bioscientifica Ltd. Printed in Great Britain 